Prepared in cooperation with the Lower Elkhorn Natural Resources District

\title{
Trends in Streamflow and Precipitation for Selected Sites in the Elkhorn River Basin and in Streamflow in the Salt Creek and Platte River Basins, Nebraska, 1961-2011
}

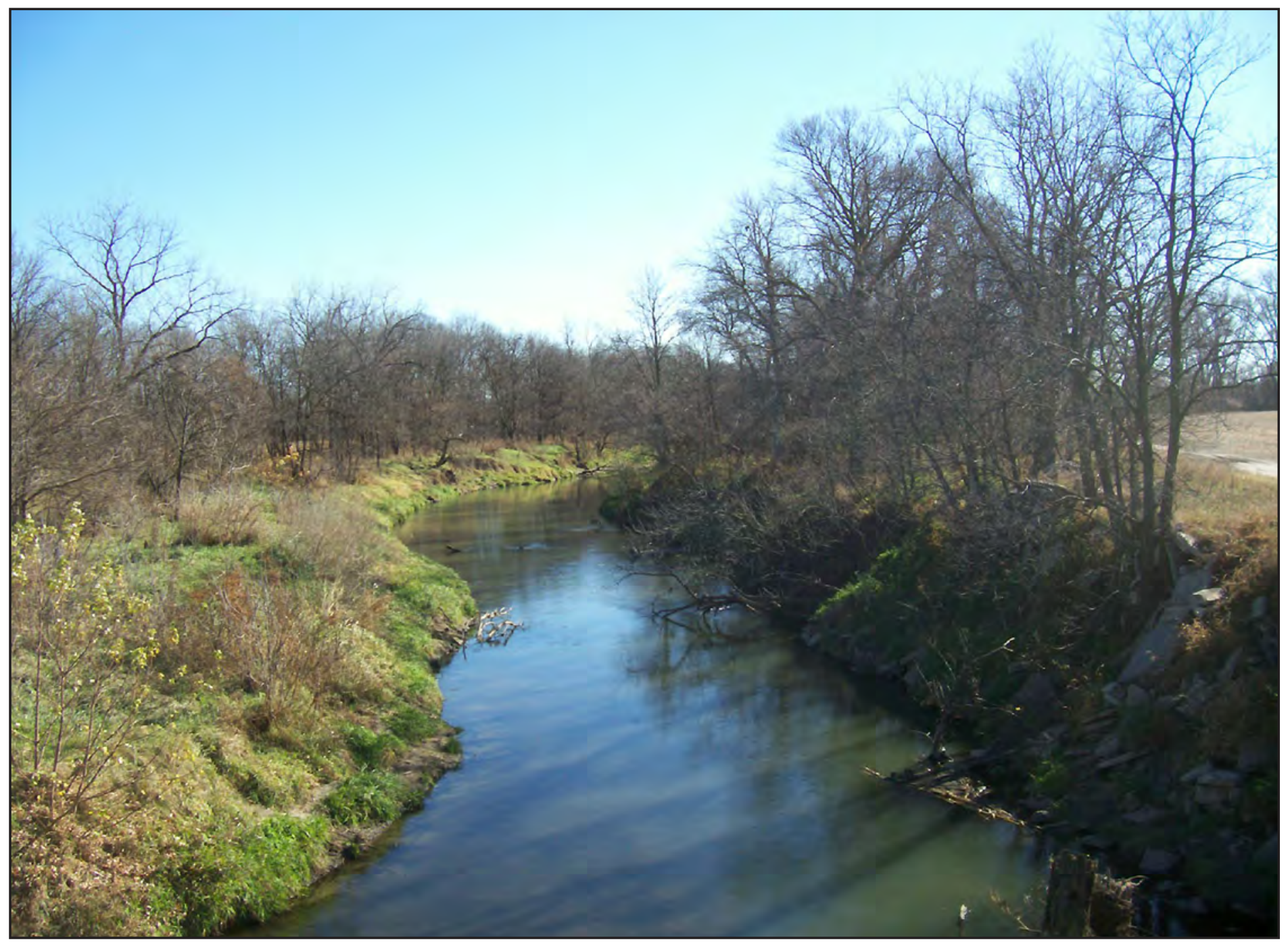

Scientific Investigations Report 2020-5016 
Cover. Photograph showing North Fork Elkhorn River near Pierce, Nebraska, downstream from the U.S. Geological Survey streamgage (station 06799100), taken November 4, 2014, by Brian Imig, U.S. Geological Survey. Stage 2.79 feet, discharge 64.7 cubic feet per second. 


\section{Trends in Streamflow and Precipitation for Selected Sites in the Elkhorn River Basin and in Streamflow in the Salt Creek and Platte River Basins, Nebraska, 1961-2011}

By Benjamin J. Dietsch and Kellan R. Strauch

Prepared in cooperation with the Lower Elkhorn Natural Resources District

Scientific Investigations Report 2020-5016 


\title{
U.S. Department of the Interior \\ DAVID BERNHARDT, Secretary
}

\author{
U.S. Geological Survey \\ James F. Reilly II, Director
}

U.S. Geological Survey, Reston, Virginia: 2020

For more information on the USGS - the Federal source for science about the Earth, its natural and living resources, natural hazards, and the environment—visit https://www.usgs.gov or call 1-888-ASK-USGS.

For an overview of USGS information products, including maps, imagery, and publications, visit https://store.usgs.gov/.

Any use of trade, firm, or product names is for descriptive purposes only and does not imply endorsement by the U.S. Government.

Although this information product, for the most part, is in the public domain, it also may contain copyrighted materials as noted in the text. Permission to reproduce copyrighted items must be secured from the copyright owner.

Suggested citation:

Dietsch, B.J., and Strauch, K.R., 2020, Trends in streamflow and precipitation for selected sites in the Elkhorn River Basin and in streamflow in the Salt Creek and Platte River Basins, Nebraska, 1961-2011: U.S. Geological Survey

Scientific Investigations Report 2020-5016, 20 p., https://doi.org/10.3133/sir20205016.

ISSN 2328-0328 (online) 


\section{Contents}

Abstract

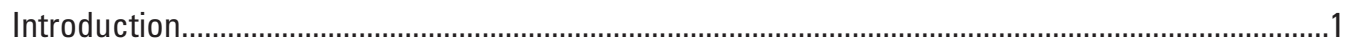

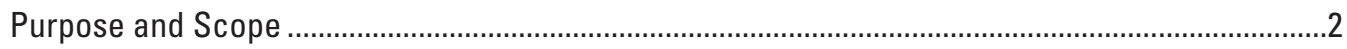

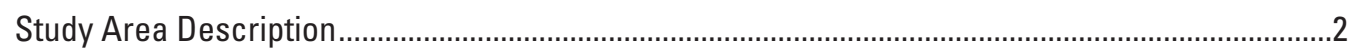

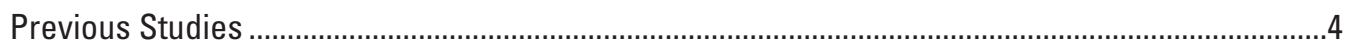

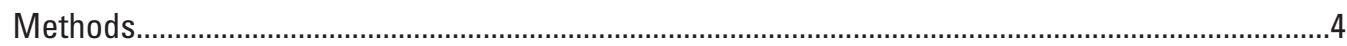

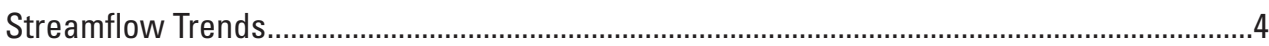

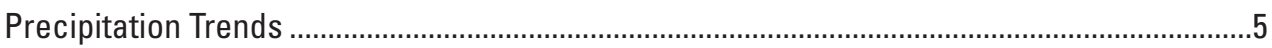

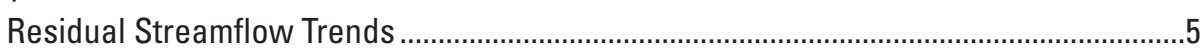

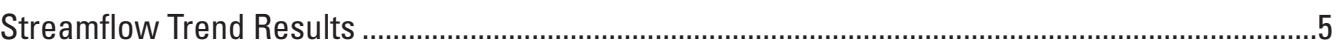

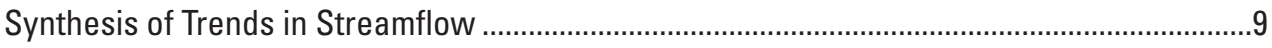

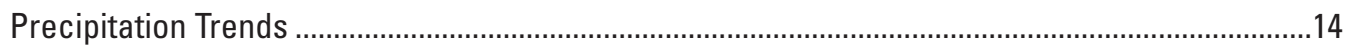

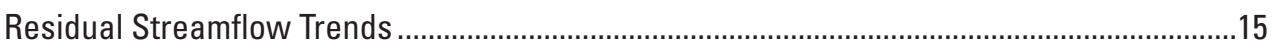

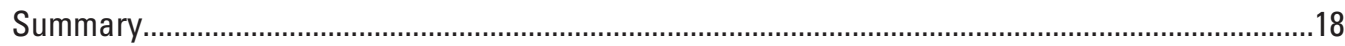

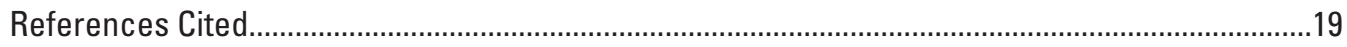

\section{Figures}

1. Map showing the study area, U.S. Geological Survey and Nebraska Department of Natural Resources streamgages, and National Oceanic and Atmospheric Administration's precipitation stations used in this study in the Elkhorn River, Salt Creek, and Platte River Basins, Nebraska ...........................................3

2. Plots showing annual mean streamflow for selected streamgages in the Elkhorn River Basin, 1961-2011 ......................................................................................

3. Plots showing annual mean streamflow for selected U.S. Geological Survey streamgages in the Platte River and Salt Creek Basins, 1961-2011 ................................9

4. Graphs showing annual water year precipitation composited for the areas upstream from four streamgages, 1961-2011

5. Plots showing annual-composited precipitation upstream from the streamgage and annual mean streamflow for four streamgages, 1961-2011.

6. Plots showing June monthly composited precipitation upgradient of the streamgage and mean June streamflow for four streamgages, 1961-2011

\section{Tables}

1. National Oceanic and Atmospheric Administration precipitation stations in or near the Elkhorn River Basin and selected streamgages in the Elkhorn River, Salt Creek, and Platte River Basins, Nebraska.

2. Percentage of Elkhorn River streamgage subbasins associated with each precipitation station

3. Trends in selected streamflow characteristics for study sites in the Elkhorn

River, Salt Creek, and Platte River Basins, Nebraska, 1961-2011 
4. Comparison of streamflow trends for the complete period of record with trends for 1961-2011 at selected sites in the Elkhorn River, Salt Creek, and Platte River Basins, Nebraska..

5. Effect of beginning year on trends in streamflow at selected sites in the Elkhorn River, Salt Creek, and Platte River Basins, Nebraska.

6. Monthly and annual trends in precipitation composited for the areas upstream from selected streamgages in the Elkhorn River Basin, Nebraska, 1961-2011

7. Monthly and annual trends in precipitation-adjusted streamflow residuals for selected streamgages in the Elkhorn River Basin, Nebraska, 1961-2011.

\section{Conversion Factors}

U.S. customary units to International System of Units

\begin{tabular}{|c|c|c|}
\hline Multiply & By & To obtain \\
\hline \multicolumn{3}{|c|}{ Length } \\
\hline inch (in.) & 2.54 & centimeter $(\mathrm{cm})$ \\
\hline foot $(\mathrm{ft})$ & 0.3048 & meter $(\mathrm{m})$ \\
\hline mile (mi) & 1.609 & kilometer $(\mathrm{km})$ \\
\hline \multicolumn{3}{|c|}{ Area } \\
\hline square mile $\left(\mathrm{mi}^{2}\right)$ & 2.590 & square kilometer $\left(\mathrm{km}^{2}\right)$ \\
\hline \multicolumn{3}{|c|}{ Flow rate } \\
\hline cubic foot per second $\left(\mathrm{ft}^{3} / \mathrm{s}\right)$ & 0.02832 & cubic meter per second $\left(\mathrm{m}^{3} / \mathrm{s}\right)$ \\
\hline inch per year (in/yr) & 25.4 & millimeter per year $(\mathrm{mm} / \mathrm{yr})$ \\
\hline
\end{tabular}

\section{Datum}

A water year begins 0 ctober 1 of the previous calendar year and ends September 30 of the year of interest. Thus, the water year ending September 30, 2011, is called the "2011 water year."

A climatic year begins April 1 and ends March 31 of the following year. A climatic year is designated by the calendar year during which most of the 12 months occur.

Horizontal coordinate information is referenced to the North American Datum of 1983 (NAD 83).

\section{Abbreviations}

LENRD Lower Elkhorn Natural Resources District

$p$-value probability value

$R^{2} \quad$ coefficient of determination

USGS U.S. Geological Survey 


\title{
Trends in Streamflow and Precipitation for Selected Sites in the Elkhorn River Basin and in Streamflow in the Salt Creek and Platte River Basins, Nebraska, 1961-2011
}

\author{
By Benjamin J. Dietsch and Kellan R. Strauch
}

\section{Abstract}

To better understand the streamflow trends at the streamgages in the Elkhorn River Basin in Nebraska, the U.S. Geological Survey (USGS) in cooperation with the Lower Elkhorn Natural Resources District further investigated streamflow trends at the eight streamgages on the Elkhorn River, Salt Creek, and the Lower Platte River that indicated a positive trend in streamflow characteristics and analyzed precipitation trends in the four basins upstream from the Elkhorn River Basin streamgages. An analysis of four streamgages in the Elkhorn River Basin, one streamgage in Salt Creek Basin, and three streamgages in the Lower Platte River Basin that had previously indicated trends in selected annual mean streamflow, annual low flows, fall low flows, and growing season monthly mean streamflows metrics were analyzed for the period from 1961 to 2011. A streamgage in the Upper Elkhorn River Basin (Elkhorn River at Neligh, Nebraska [USGS station 06798500; maintained by USGS from water years 1930 to 1993 , maintained by Nebraska Department of Natural Resources from water years 1994 to 2019]) had significant positive trends in annual mean streamflow and insignificant trends for other streamflow metrics whereas the lower three sites (Logan Creek near Uehling, Nebr. [USGS station 06799500]; Maple Creek at Nickerson, Nebr. [USGS station 06800000]; and Elkhorn River at Waterloo, Nebr. [USGS station 06800500]) had significant positive trends for annual mean streamflow, for all durations of the annual low-flow periods (1-day, 2-day, 3-day, 7-day, 14-day, 30-day, 60-day, 90-day, and 183-day periods), for all durations of the low-flow periods in October-November (1-day, 2-day, 3-day, 7-day, 14-day, 30-day, and 60-day periods), and for monthly mean streamflow for July, August, and September. Upstream from the confluence of the Elkhorn River and the Platte River, the Platte River at North Bend, Nebr. (USGS station 06796000), streamgage indicated insignificant trends for most streamflow metrics. A streamgage in the Salt Creek Basin (Salt Creek at Greenwood, Nebr. [USGS station 06803555]) also indicated positive trends in some low-flows metrics. Streamflow at the Platte River at Louisville, Nebr. (USGS station 06805500), streamgage, downstream from the Salt Creek and Elkhorn
River inflows, indicated significant positive trends in most annual and all October-November low flows and August mean streamflow but insignificant trends in annual mean streamflow and June, July, and September monthly mean streamflows. Streamflow records for the Platte River near Duncan, Nebr. (USGS station 06774000), streamgage only indicated a significant trend in the August mean streamflow; no other metrics had significant trends at the streamgage.

The trend analyses are sensitive to the period that is analyzed for trends. Sites with the most significant trends for lowflow metrics for the period 1961-2011 have fewer significant trends for low-flow metrics for the period after 1980-2011.

The results indicate that positive trends in low flows at the Salt Creek and Elkhorn River streamgages may be contributing to positive trends in low flows for the Platte River at Louisville, Nebr., streamgage. Likewise, streamflow in the Salt Creek and Elkhorn River Basins may be contributing to the positive trend in August mean streamflow for the Platte River at Louisville, Nebr., streamgage, three lower Elkhorn River streamgages, and the Salt Creek streamgage.

Precipitation was also examined as a primary cause for streamflow trends in the Elkhorn River Basin. For the four streamgages in the Elkhorn River Basin, relations between precipitation and streamflow were examined on an annual and monthly basis using linear regression. In general, the goodness of fit for the linear relations was poor with coefficient of determination values of less than or equal to 0.10 for four of the eight relations. Only one significant increase in annual precipitation upstream from the four streamgages and the frequent detection of significant increases in streamflow after removing the effect of precipitation indicate that other factors besides precipitation may have played a role in the significant positive trends in low-flow periods in the lower Elkhorn River and its tributaries.

\section{Introduction}

The sustainability of water resources in the Elkhorn River Basin is a critical issue for Nebraska (fig. 1).

Understanding streamflow trends is important in determining 
Streamflow and Precipitation for the Elkhorn River Basin and Streamflow in the Salt Creek and Platte River Basins, Nebr.

the sustainable use of surface water and groundwater in the Elkhorn River Basin. Nebraska State Statute, section 46-713 of the Ground Water Management and Protection Act (https://nebraskalegislature.gov/laws/statutes.php?statute=46713), requires the Nebraska Department of Natural Resources to annually evaluate the expected long-term availability of hydrologically connected water supplies. This annual evaluation is required for every river basin, subbasin, or reach that has not previously been determined to be fully or overappropriated; at the present time (2020), an annual evaluation is required for the Elkhorn River Basin. As such, the Lower Elkhorn Natural Resources District (LENRD) is collecting data and developing water-management strategies to assist with water-resources planning. Specifically, the LENRD is concerned with the effect of groundwater withdrawal on the availability of surface water and the long-term effects of groundwater withdrawal on groundwater and surface-water resources.

Previously, the LENRD, the Upper Elkhorn Natural Resources District, and the U.S. Geological Survey (USGS) cooperatively studied trends in streamflow characteristics of streamgages in the Elkhorn River, Salt Creek, and Lower Platte River Basins to provide information for developing water-resources management and planning strategies (Dietsch and others, 2009). The study examined the contributions of streamflow from major tributaries (Elkhorn River and Salt Creek) to the Lower Platte River. The results of the study indicated positive (upward) temporal trends in streamflow for the period of record at eight streamgages. The trend analysis for the study was completed on the period of record at each streamgage; therefore, the period of analysis was not consistent from one streamgage to another. In addition, precipitation, often the primary driver of streamflow, was not analyzed for trends as part of Dietsch and others (2009). Trends in precipitation that exist over the same period as trends in streamflow might indicate that streamflow trends are the result of changes in precipitation. To better understand the trends at the streamgages, in this present study, the USGS in cooperation with the LENRD further investigated streamflow trends at the eight streamgages on the Elkhorn River, Salt Creek, and the Lower Platte River Basins that indicated a positive trend in streamflow characteristics and analyzed precipitation in the four basins upstream from the Elkhorn River Basin streamgages.

\section{Purpose and Scope}

The purpose of this report is to present the trends in 20 selected streamflow metrics (annual mean streamflow, annual low flows, fall low flows, and growing season monthly mean streamflows) for four streamgages in the Elkhorn River Basin, one streamgage in the Salt Creek Basin, and three streamgages in the Platte River Basin for a common period (from 1961 to 2011). This report also describes the detection of streamflow trends on subsets of the period of record. In addition, the results of tests for trends in precipitation and for precipitation-adjusted streamflow in the basins are presented.

\section{Study Area Description}

The study area includes streamgages on the Elkhorn River (Elkhorn River at Neligh, Nebr. [USGS station 06798500; maintained by USGS from water years 1930 to 1993, maintained by Nebraska Department of Natural Resources from water years 1994 to 2019]; Logan Creek near Uehling, Nebr. [USGS station 06799500]; Maple Creek near Nickerson, Nebr., [USGS station 06800000]; and Elkhorn River at Waterloo, Nebr. [USGS station 06800500]), Salt Creek (Salt Creek at Greenwood, Nebr. [USGS station 06803555]), and the Lower Platte River (Platte River near Duncan, Nebr. [USGS station 06774000]; Platte River at North Bend, Nebr. [USGS station 06796000]; and Platte River at Louisville, Nebr. [USGS station 06805500]; fig. 1). The confluences of the Elkhorn River and Salt Creek with the Platte River are within a reach of the Platte River that is important to instream flow rights (Nebraska Department of Natural Resources, 2013) and municipal water supplies (Steele and Verstraeten, 1999).

The Elkhorn River Basin is in northeastern Nebraska (fig. 1), within two distinct landforms - the migrating sand dunes to the west and the windblown loess deposits to the east (Bentall and others, 1971), and has a drainage area of 5,870 square miles $\left(\mathrm{mi}^{2}\right)$ at the USGS streamgage Elkhorn River at Waterloo, Nebr. The Elkhorn River flows eastsoutheast through the Sand Hills in north-central Nebraska and the glacial till of northeastern Nebraska and joins the Platte River about 20 miles (mi) downstream from Fremont, Nebr. (Bentall and others, 1971). The topography is characteristic of many basins in Nebraska, with a moderately flat surface near the stream transitioning to rolling hills and dunes or loess deposits at the basin margins. The Elkhorn River streamflow is fairly uniform throughout the year with base flow provided by groundwater; however, the possibility for large precipitation events in the spring, coupled with winter thaw and snowmelt runoff, can produce large rises in stream stage and large increases in streamflow. Logan Creek, a principal tributary of the Elkhorn River that drains much of the glaciated area of northeastern Nebraska, enters the Elkhorn River north of Fremont, Nebr. (fig. 1). The flow regimes of the eastern and western parts of the Elkhorn River Basin contrast because of the differences in the sediment composition and the positive (increasing) gradient of precipitation from west to east (Bentall and others, 1971). Streamflows in the Sand Hills or western part of the Elkhorn River Basin, which is characterized by extremely permeable sediments, are derived primarily from groundwater as base flow. In contrast, streamflows in the eastern part of the Elkhorn River Basin, where loesscapped glacial deposits generally are less permeable, are more 


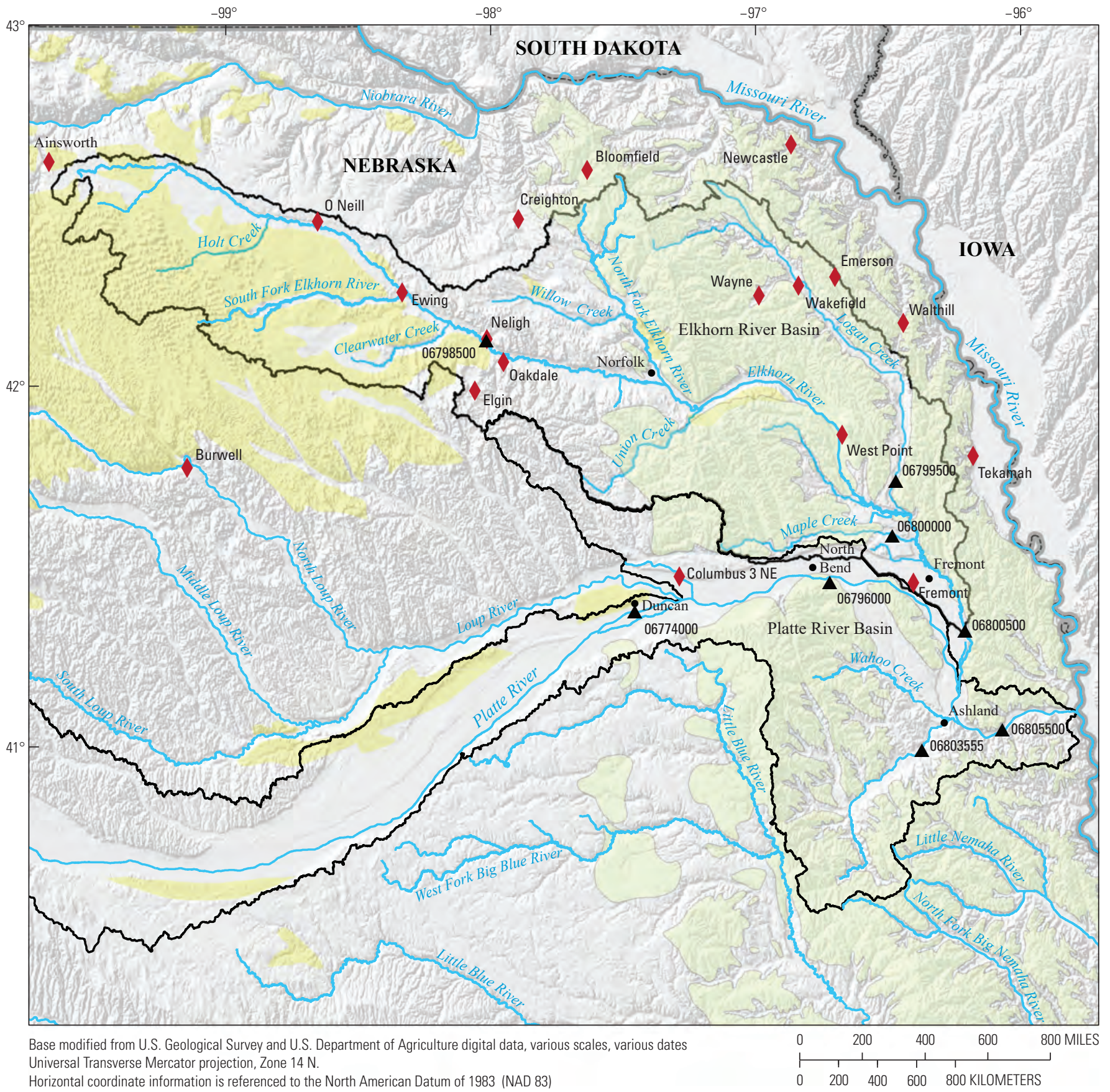

EXPLANATION

Surficial geology

Sand Hills-Adapted from U.S. Soil Conservation Service, 1970, 1:2,000,000

Glaciated till-Conservation and Survey Division, University of Nebraska-Lincoln, 2019

Basin boundary
06774000 Streamgage and station number

Fremont $>$ Precipitation station and name

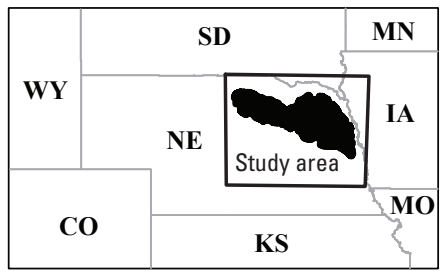

Figure 1. Study area, U.S. Geological Survey and Nebraska Department of Natural Resources streamgages, and National Oceanic and Atmospheric Administration's precipitation stations used in this study in the Elkhorn River, Salt Creek, and Platte River Basins, Nebraska. 
Streamflow and Precipitation for the Elkhorn River Basin and Streamflow in the Salt Creek and Platte River Basins, Nebr.

variable and responsive to precipitation events. Surface-water use in the Elkhorn River Basin includes irrigation, livestock, and recreational supplies. Extensive straightening on the Elkhorn River and some of its tributaries, including Logan Creek and Maple Creek, from the 1910s through the 1960s contributed to streambed adjustments of as much as 10 feet (ft) of degradation in some parts of the basin (Rus and others, 2003).

Salt Creek, whose confluence with the Platte River is about $7 \mathrm{mi}$ downstream from the confluence of the Elkhorn and Platte Rivers (fig. 1), flows north to northeast through southeastern Nebraska. The 1,650-mi² Salt Creek Basin generally slopes from southwest to northeast. Wahoo Creek, a principal tributary of Salt Creek, enters Salt Creek near Ashland, or upstream from the confluence with the Platte River. The Platte River is a braided stream that begins at the confluence of the North Platte and South Platte Rivers near North Platte, Nebr. (not shown), and has a drainage area of about $71,000 \mathrm{mi}^{2}$ at the Platte River at Louisville, Nebr., streamgage (fig. 1).

\section{Previous Studies}

Several investigations of annual mean streamflow trends have been completed on nationwide and regional scales (Lins and Slack, 1999; McCabe and Wolock, 2002). Results of these studies indicated positive (upward) trends in median and low flows in the upper Midwest, including the Elkhorn River Basin.

Dietsch and others (2009) detected increases in annual mean streamflow, monthly streamflows, and low flows by applying the Kendall's tau nonparametric test at selected sites within the Elkhorn River Basin. The increases in annual mean streamflow conflicted with similar studies to detect trends at streamgages in Nebraska (Wen and Chen, 2006). However, different periods were used for the Wen and Chen (2006) analysis, and the probability values for three streamgages in the Elkhorn River Basin (Logan Creek near Uehling, Nebr.; Maple Creek near Nickerson, Nebr.; and Elkhorn River at Waterloo, Nebr.) were characterized as having insignificant trends because each of the three streamgages had probability $(p)$ values within 0.024 of the significance level $(0.05)$. Wen and Chen (2006) also investigated trends in annual mean streamflows by adjusting for annual precipitation; however, analysis was limited to the Republican River (not shown).

More recent research (Norton and others, 2014) indicated that sites in the western and southern parts of the Missouri River Basin (not shown) had downward trends in annual mean streamflow, whereas the eastern part of the Missouri River Basin, including the Elkhorn River Basin, had positive trends in streamflow. Trends in precipitation and the possible effects on streamflow trends have not been investigated in detail for the Elkhorn River Basin.

\section{Methods}

Trends in long-term streamflow at the eight sites were assessed using Kendall's tau test, a nonparametric method to detect trends in time-series data (Helsel and Hirsch, 1992). The four streamgages in the Elkhorn River Basin were selected because the previous studies (see "Previous Studies" section of this report) indicated trends in at least one streamflow metric, and because each streamgage represents a major subbasin (with the exception of Elkhorn River at Waterloo, Nebr., which integrates flows from the basin). The streamgages on the Platte River and Salt Creek that are near the Elkhorn River's confluence with the Platte River were included to expand on the analysis done in previous studies and to determine if significant trends in the Lower Platte River were concurrent with trends in the major Lower Platte River tributaries. A total of 20 streamflow metrics were tested in this study: annual mean streamflow, 1-day low flow, 2-day low flow, 3-day low flow, 7-day low flow, 14-day low flow, 30-day low flow, 60-day low flow, 90-day low flow, 183-day low flow, 1-day low flow (October-November), 3-day low flow (October-November), 7-day low flow (October-November), 14-day low flow (October-November), 30-day low flow (October-November), 60-day low flow (October-November), June mean flow, July mean flow, August mean flow, and September mean flow.

National Oceanic and Atmospheric Administration's meteorological data for U.S. Climate Reference Network precipitation stations (Diamond and others, 2013) were compiled for 18 long-term precipitation stations in the study area that were in or near the Elkhorn River Basin (fig. 1; table 1). Daily precipitation data for 1961-2011 from the precipitation stations were obtained from the U.S. Climate Reference Network (Diamond and others, 2013). The Kendall's tau test was used to detect temporal trends in the time-series data representing precipitation in the area above each streamgage. The Kendall's tau test was completed on annual and monthly mean precipitation data.

\section{Streamflow Trends}

Daily streamflow records were used to compute streamflow characteristics for eight long-term streamgages in the Elkhorn River Basin and adjacent basins. All eight of the streamgages (table 1) were established by the USGS before October 1, 1960, and were operated as continuous recording streamgages through 2011 or longer. Since 1994, the streamgage on the Elkhorn River at Neligh, Nebr., has been operated by the Nebraska Department of Natural Resources. Streamflow records are available through the USGS National Water Information System database (U.S. Geological Survey, 2017) and from the Nebraska Department of Natural Resources (Nebraska Department of Natural Resources, 2017). Periods of streamgage operation ranged from 1896 to present (2020) in the Platte River and Elkhorn River Basins 
and from the 1950s to present in the Salt Creek Basin. Periods of daily streamflow records at these sites ranged from 1928 to 2013. The time frame used for trend analysis was limited to 1961-2011, which provided a common period of analysis across the streamgages. Daily streamflows were aggregated to monthly mean streamflows and annual mean streamflows. Additionally, low-flow characteristics were computed as the lowest mean streamflow over a specified number of consecutive days in a given period ( $n$-day). Annual low-flow indices were computed for 1-, 2-, 3-, 7-, 14-, 30-, 60-, 90-, and 183-day intervals. Because low flows are common during the fall season, an additional set of low-flow indices was computed specifically for the bimonthly period of OctoberNovember for 1-, 2-, 3-, 7-, 14-, 30-, and 60-day intervals.

The annual mean streamflows were computed using the water year. A water year begins October 1 of the previous calendar year and ends September 30 of the year of interest. The annual low flows ( $n$-day) were computed using the climatic year, which begins April 1 and ends March 31. Climatic years typically are used in low-flow analyses because low flows in much of the United States are common in late summer and early fall, and the designation of the flow period by water year may separate one low-flow period into 2 water years.

Trends in long-term streamflow at the eight streamgages were assessed using Kendall's tau test, a nonparametric method to detect trends in time-series data (Helsel and Hirsch, 1992). The tau statistic is a measure of the level of monotonic positive (upward) or negative (downward) change in a dataset over time; a tau value of +1 indicates each element in the series is greater than the previous element in the series, and -1 indicates each element in the series is less than the previous element in the series. The probability that the tau test identifies a trend when none actually exists is represented by the $p$-value. For this study, a significance level of 0.95 ( $p$-value less than or equal to 0.05) was used to declare a trend. At each site, Kendall's tau tests were completed for annual mean streamflows; monthly mean streamflows for June, July, August, and September; annual low flows ( $n$-day); and bimonthly (October-November) low flows ( $n$-day) for the period of 1961-2011.

Linear-regression analyses (using ordinary least-squares techniques) were used to estimate the trend slope in timeseries data for sites with significant temporal trends. This slope represents the median magnitude of the annual increase or decrease in the respective streamflow statistic over the period analyzed.

\section{Precipitation Trends}

NWS precipitation data were compiled for 18 long-term precipitation stations in the study area that were in or near the Elkhorn River Basin (fig. 1; table 1). Daily precipitation data for 1961-2011 from the stations were obtained from the U.S. Climate Reference Network (Diamond and others, 2013).
Using the data from the NWS precipitation stations, composite precipitation time series were created for the basins of the four streamgages in the Elkhorn River Basin. The Thiessen method (Linsley and others, 1982) was used to delineate the representative areas associated with each of the 18 NWS precipitation stations. The fractions of the Thiessen areas overlapping the drainage area of the four streamgages were used to compute areal weighting factors (table 2). The NWS precipitation data were then multiplied by those factors and summed to derive a composite rainfall time series for each streamgage.

The Kendall's tau test was used to detect temporal trends in the composite time-series data representing precipitation in the drainage area upstream from each streamgage. The Kendall's tau test was completed on annual and monthly mean precipitation data.

\section{Residual Streamflow Trends}

Linear-regression models were constructed to relate precipitation to streamflow. The annual or monthly precipitation value was fit to the log-transformed streamflow for the corresponding year using linear regression in the R statistical software (Venables and others, 2017). The residual annual mean streamflow was then computed by applying each precipitation time series (annual and monthly) as an input to the linear models to calculate a predicted streamflow; then, the predicted streamflow was subtracted from the observed streamflow to compute residual streamflow. The Kendall's tau test was then applied to the resulting times series of residual values.

\section{Streamflow Trend Results}

Streamflow trends for a variety of flow periods at the eight streamgages for the 1961-2011 period are listed in tables 3, 4, and 5. Although five of the eight streamgages did not indicate significant trends in water year annual mean streamflow (figs. 2 and 3), significant trends in streamflow during low-flow periods or months during the growing season were detected at seven of the eight streamgages (table 3). All the significant trends in streamflow metrics were positive, indicating increases in streamflow over time.

All four streamgages in the Elkhorn River Basin had previously indicated positive trends in streamflows when computed for their periods of record (Dietsch and others, 2009). With a few exceptions, those trends were maintained when the analyses were constrained to the 1961-2011 period for this study (table 3). Annual mean streamflows at the Elkhorn River at Neligh, Nebr., streamgage indicated a significant positive trend, but trends during low-flow periods or in growing season monthly mean streamflow were not significant. This finding is in contrast to similar analyses done for the 1931-2003 period that identified positive trends in several low-flow characteristics at this site (Dietsch and others, 2009). This finding is also in contrast to the fall low-flow trends and 
Table 1. National Oceanic and Atmospheric Administration precipitation stations in or near the Elkhorn River Basin and selected streamgages in the Elkhorn River, Salt Creek, and Platte River Basins, Nebraska.

[Nebr., Nebraska; --, no data]

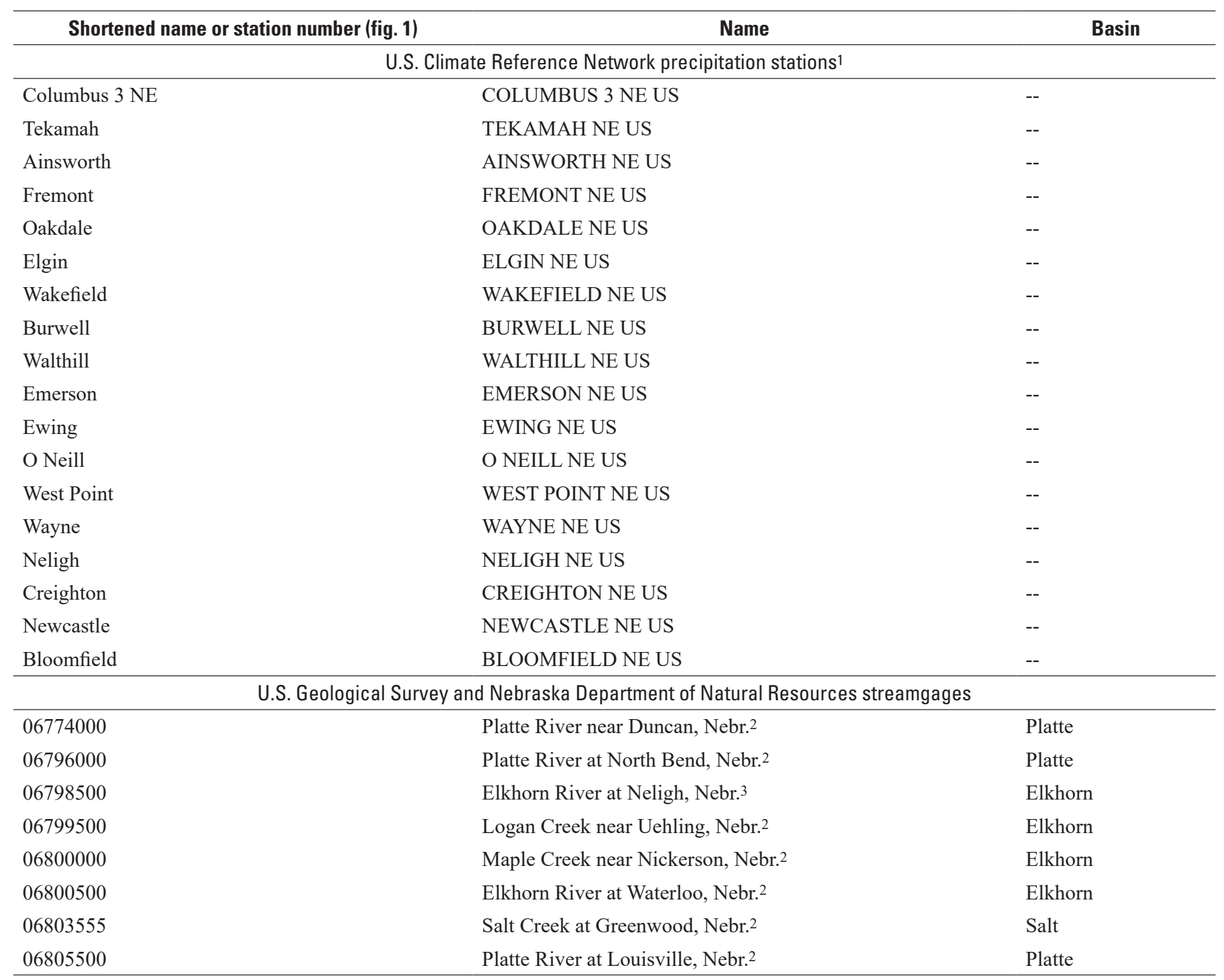

1Precipitation station data from U.S. Climate Reference Network (Diamond and others, 2013).

${ }^{2}$ Streamgage data from the U.S. Geological Survey.

${ }^{3}$ Streamgage operated by U.S. Geological Survey from water years 1930 to 1993, maintained by Nebraska Department of Natural Resources from water years 1994 to 2019.

growing season monthly mean streamflow trends detected for the other three streamgages in the Elkhorn River Basin for this study. Trends in annual mean streamflows were detected for the Logan Creek near Uehling, Nebr., and Elkhorn River at Waterloo, Nebr., streamgages but not for the Maple Creek near Nickerson, Nebr., streamgage. Trend analyses indicated significant positive trends at the Logan Creek near Uehling, Nebr.; Maple Creek near Nickerson, Nebr.; and Elkhorn River at Waterloo, Nebr., streamgages for all the annual low-flow indices, all the fall low-flow indices, and the monthly mean streamflow for July, August, and September (table 3).
Streamflow records for the Platte River near Duncan, Nebr., and the Platte River at North Bend, Nebr., streamgages did not indicate significant trends in annual mean streamflow (table 3). Both streamgages incorporate the hydrologic responses of the Platte River upstream from the Elkhorn River confluence, but the Platte River at North Bend, Nebr., streamgage also includes responses of the Loup River, a major tributary to the Platte River. The Platte River near Duncan, Nebr., and the Platte River at North Bend, Nebr., streamgages indicated no significant trends in most of the annual lowflow characteristics; however, a significant positive trend 
Table 2. Percentage of Elkhorn River streamgage subbasins associated with each precipitation station.

[Nebr., Nebraska; GHCND, Global Historical Climatology Network Daily]

\begin{tabular}{|c|c|c|c|c|c|}
\hline \multicolumn{2}{|c|}{ Precipitation station } & \multicolumn{4}{|c|}{$\begin{array}{l}\text { U.S. Geological Survey and Nebraska Department of Natural Resources streamgages } \\
\text { and station numbers }\end{array}$} \\
\hline Station number & $\begin{array}{l}\text { Short name } \\
\text { (fig. 1) }\end{array}$ & $\begin{array}{c}\text { Elkhorn River at } \\
\text { Neligh, Nebr., } \\
\text { station } 067985001\end{array}$ & $\begin{array}{l}\text { Logan Creek near } \\
\text { Uehling, Nebr., } \\
\text { station } 06799500^{2}\end{array}$ & $\begin{array}{l}\text { Maple Creek near } \\
\text { Nickerson, Nebr., } \\
\text { station } 06800000^{2}\end{array}$ & $\begin{array}{l}\text { Elkhorn River at } \\
\text { Waterloo, Nebr., } \\
\text { station 068005002 }\end{array}$ \\
\hline GHCND:USC00256135 & Oakdale & 0.1 & 11.1 & 0 & 0 \\
\hline GHCND:USC00259200 & West Point & 0 & 13.7 & 13 & 39.2 \\
\hline GHCND:USC00251990 & Creighton & 0 & 2.9 & 0 & 0 \\
\hline GHCND:USC00255830 & Neligh & 4.7 & 3.6 & 0 & 0 \\
\hline GHCND:USC00252595 & Elgin & 7.8 & 2.7 & 0 & 0 \\
\hline GHCND:USC00259045 & Wayne & 0 & 13.9 & 38.5 & 0 \\
\hline GHCND:USC00258935 & Walthill & 0 & 1.9 & 12.4 & 0 \\
\hline GHCND:USC00258915 & Wakefield & 0 & 2.7 & 16.5 & 0 \\
\hline GHCND:USC00253050 & Fremont & 0 & 5.2 & 0 & 12.6 \\
\hline GHCND:USC00258480 & Tekamah & 0 & 2.5 & 1.7 & 0 \\
\hline GHCND:USC00251825 & Columbus $3 \mathrm{NE}$ & 0 & 6.7 & 0 & 48.2 \\
\hline GHCND:USC00250945 & Bloomfield & 0 & 3.2 & 3.2 & 0 \\
\hline GHCND:USC00251345 & Burwell & 5.8 & 1.8 & 0 & 0 \\
\hline GHCND:USC00255895 & Newcastle & 0 & 1 & 6.9 & 0 \\
\hline GHCND:USC00250050 & Ainsworth & 19.4 & 6.2 & 0 & 0 \\
\hline GHCND:USC00252805 & Ewing & 20.2 & 6.4 & 0 & 0 \\
\hline GHCND:USC00252715 & Emerson & 0 & 1.1 & 7.8 & 0 \\
\hline GHCND:USC00256290 & O Neill & 42 & 13.4 & 0 & 0 \\
\hline
\end{tabular}

1Streamgage operated by the U.S. Geological Survey from water years 1930 to 1993, maintained by Nebraska Department of Natural Resources from water years 1994 to 2019 .

${ }^{2}$ Streamgage data from the U.S. Geological Survey.

was detected for August mean streamflows. No trends were detected in the fall low-flow statistics at either streamgage. August mean streamflows at both sites indicated a significant positive trend. Monthly mean streamflows in June, July, and September were insignificant for the Platte River near Duncan, Nebr., and the Platte River at North Bend, Nebr., streamgages.

Annual mean streamflow at the Salt Creek at Greenwood, Nebr., streamgage, which is on a tributary of the Platte River that enters downstream from the Elkhorn River and contributes to streamflows at the Platte River at Louisville, Nebr., streamgage, did not have a significant trend for the period (table 3). However, significant positive trends were indicated for all the low-flow periods. Of the monthly mean streamflows during the growing season, only August had a significant positive trend for the Salt Creek at Greenwood, Nebr., streamgage.

The Platte River at Louisville, Nebr., streamgage, which is downstream from all major tributaries, including the Elkhorn River and Salt Creek, integrates the streamflow trends from all the upstream sites. Annual mean streamflow at the Platte River at Louisville, Nebr., streamgage did not have a significant trend for the period (table 3); however, significant positive trends are indicated for most annual and all OctoberNovember low-flow periods. Monthly mean streamflows during the growing season in August had a significant positive trend, whereas streamflows for June, July, and September were not significant at the Platte River at Louisville, Nebr., streamgage.

Significant trends over a full period of record for a streamgage were compared to the 1961-2011 period (table 4). For the 20 streamflow metrics tested in this study, most trends that were significant for the full period of record were also significant for the 1961-2011 period. Of the trends that were different, depending on the analysis period, all but one trend was significant for the full period and insignificant for the 1961-2011 period. The remaining trend indicated insignificant trends for the full period of record but significant trends for 1961-2011. A description of the changes in significance status follows. For three streamgages (Maple Creek near Nickerson, Nebr.; Salt Creek at Greenwood, Nebr.; and Platte River at Louisville, Nebr.), a positive significant trend in annual mean streamflows was indicated for the full period of record; however, when the period of analysis was limited to 1961-2011, 

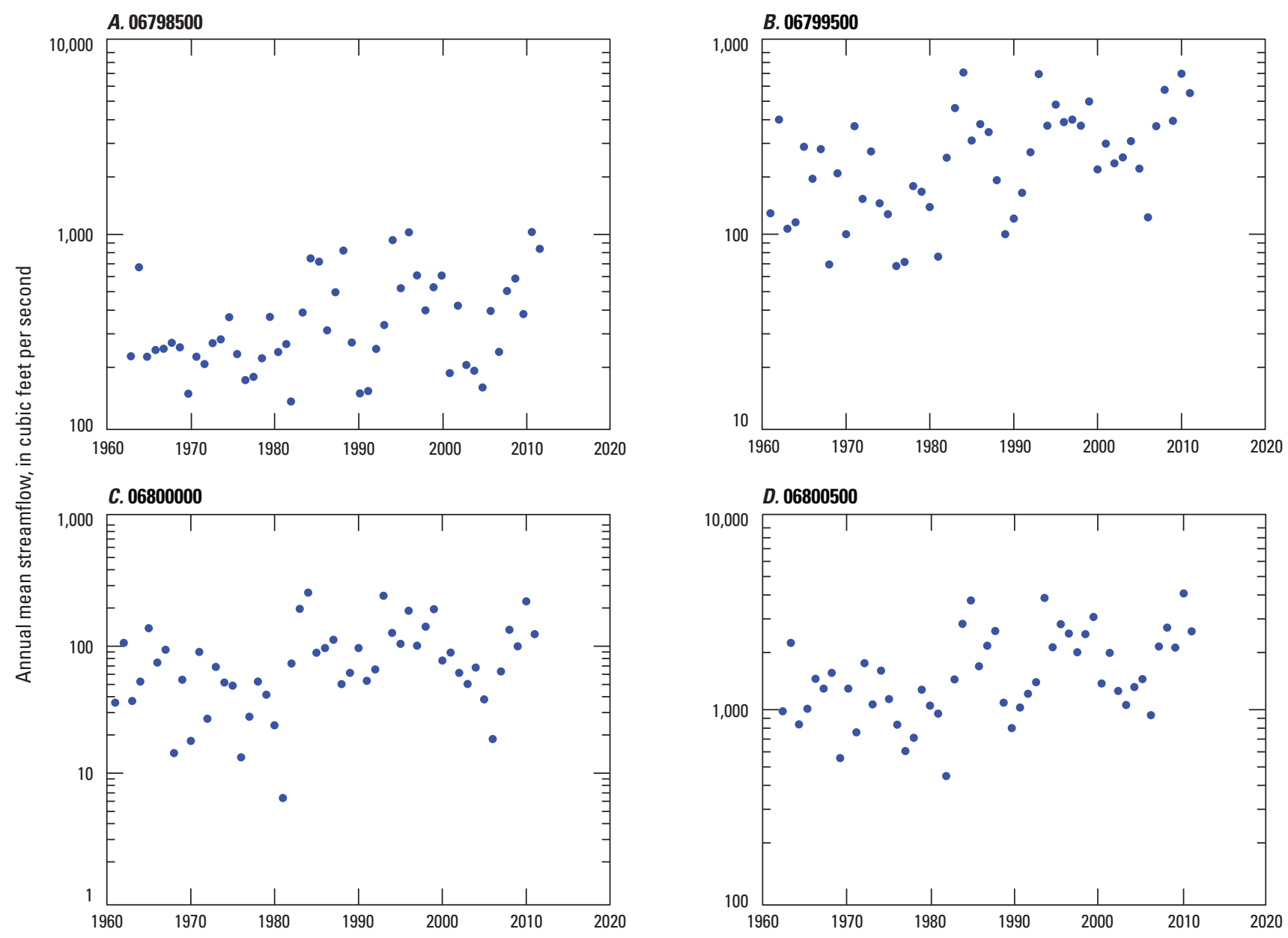

Water year

EXPLANATION

- Observed, annual

Figure 2. Plots of annual mean streamflow for selected streamgages in the Elkhorn River Basin, 1961-2011. A, Nebraska Department of Natural Resources Elkhorn River at Neligh, Nebraska (station 06798500); B, U.S. Geological Survey Logan Creek near Uehling, Nebr. (station 06799500); C, U.S. Geological Survey Maple Creek near Nickerson, Nebr. (station 06800000); D, U.S. Geological Survey Elkhorn River at Waterloo, Nebr. (station 06800500).

the trends were insignificant. For three streamgages (Elkhorn River at Neligh, Nebr.; Logan Creek near Uehling, Nebr.; and Elkhorn River at Waterloo, Nebr.), a positive significant trend in annual mean streamflows was indicated for the full period of record and the 1961-2011 period. For fall low-flow periods, trends that were significant for the full period of record were also significant for the 1961-2011 period with exceptions at three sites (Elkhorn River at Neligh, Nebr.; Platte River at North Bend, Nebr.; and Platte River near Duncan, Nebr.). At the Elkhorn River at Neligh, Nebr., streamgage, all fall lowflow metrics indicated significant trends for the full period of record but no significant trends for 1961-2011. At the Platte River at North Bend, Nebr., streamgage, October-November low-flow periods except the 1-day low flow indicated significant trends for the full period of record but no significant trends for 1961-2011. The streamflow record for the Platte River near Duncan, Nebr., streamgage indicated significant positive trends in all low flows and in all October-November low-flow durations over the full period of record but no significant trends for 1961-2011, with the exception of August monthly mean streamflow.

The starting year of the period for trend analysis was varied to further examine whether trends were evenly distributed over time or streamflows changed during more distinct periods. Kendall's tau was calculated for streamflow characteristics on progressively shorter periods ending in 2011. A procedure was followed whereby the starting year of the period analyzed was advanced 1 year and Kendall's tau was computed. This procedure was done such that Kendall's tau was computed for the periods of 1961-2011, 1962-2011, 

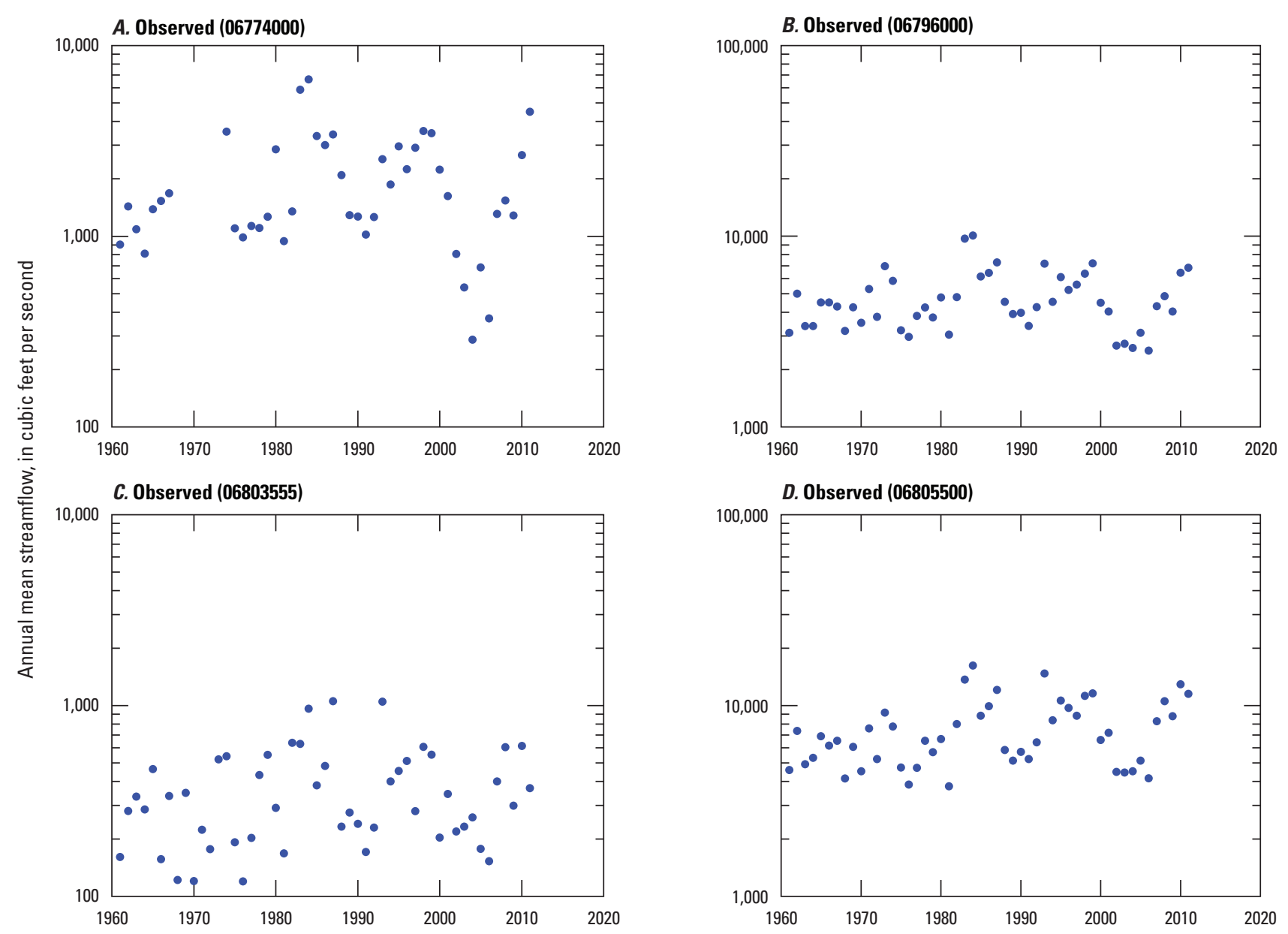

Water year

EXPLANATION

- Observed, annual

Figure 3. Plots of annual mean streamflow for selected U.S. Geological Survey streamgages in the Platte River and Salt Creek Basins, 1961-2011. A, Platte River near Duncan, Nebraska (station 06774000); B, Platte River at North Bend, Nebr. (station 06796000); C, Salt Creek at Greenwood Nebr. (station 06803555); D, Platte River at Louisville, Nebr. (station 06805500).

1963-2011, and so on until the period of 2001-11 was examined. Periods shorter than 2001-11 were considered to be too short for the Kendall's tau analysis. The results of the progressive shortening of the period of analysis indicate that many of the stream characteristics with significant trends for the period of 1961-2011 become insignificant for the period from about 1974 to 1977 through 2011 (table 5).

\section{Synthesis of Trends in Streamflow}

The annual mean streamflow trends for the eight sites in this study agree with the findings of McCabe and Wolock (2002) and Norton and others (2014), which were significant positive (upward) trends in annual, seasonal, and monthly streamflow. Wen and Chen (2006) determined no significant trends in the Elkhorn River Basin for the period of 1960 to 2003 for annual mean streamflows; however they reported $p$-values close to significance for three of the streamgages in this study (Logan Creek near Uehling, Nebr.; Maple Creek near Nickerson, Nebr.; and Elkhorn River at Waterloo, Nebr.).

For most streamflow metrics at most sites in this study, significant trends do not become insignificant or negative (downward) if the period of record is contracted from the full period of record to 1961-2011(table 5). Annual and low-flow trends tend to become insignificant after about the mid-1970s for streamgages in the lower Elkhorn River Basin (table 5). This finding indicates that in the 20 -year period before about 1980 , the streams in this study carried less streamflow during low-flow periods than in the 30 years after. 
Table 3. Trends in selected streamflow characteristics for study sites in the Elkhorn River, Salt Creek, and Platte River Basins, Nebraska, $1961-2011$.

[Significant trends had probability values less than or equal to 0.05 ; Oct., October; Nov., November; Nebr., Nebraska; I, insignificant trend; P, significant trend]

\begin{tabular}{|c|c|c|c|c|c|c|c|c|c|c|c|c|c|c|c|c|c|c|c|c|c|c|}
\hline \multirow{2}{*}{\multicolumn{2}{|c|}{$\begin{array}{l}\text { U.S. Geological Survey and } \\
\text { Nebraska Department of Natural } \\
\text { Resources streamgages }\end{array}$}} & \multirow[b]{2}{*}{$\begin{array}{c}\text { Period } \\
\text { analyzed }\end{array}$} & \multirow{2}{*}{ 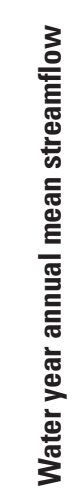 } & \multicolumn{9}{|c|}{ Climatic year annual low flows } & \multicolumn{6}{|c|}{ Fall low flows } & \multicolumn{4}{|c|}{$\begin{array}{c}\text { Growing season } \\
\text { monthly mean flows }\end{array}$} \\
\hline & & & & $\begin{array}{l}\frac{3}{0} \\
\frac{0}{4} \\
\frac{3}{0} \\
\frac{\pi}{2} \\
\frac{\pi}{1}\end{array}$ & $\begin{array}{l}\frac{3}{0} \\
\frac{0}{4} \\
\frac{3}{0} \\
\frac{\pi}{i} \\
\text { ì }\end{array}$ & $\begin{array}{l}\frac{3}{0} \\
\frac{0}{4} \\
\frac{3}{0} \\
\frac{\pi}{\bar{x}} \\
\text { m. }\end{array}$ & $\begin{array}{l}\frac{3}{0} \\
\frac{0}{4} \\
\frac{3}{0} \\
\frac{\pi}{i} \\
i \\
i\end{array}$ & $\begin{array}{l}\frac{3}{0} \\
\frac{1}{3} \\
\frac{3}{0} \\
\frac{\pi}{0} \\
\frac{1}{1} \\
\frac{1}{2}\end{array}$ & 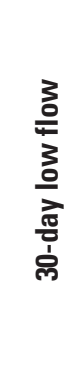 & 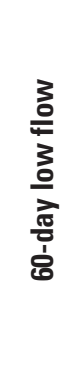 & $\begin{array}{l}\frac{3}{0} \\
\frac{0}{4} \\
\frac{3}{0} \\
\frac{\pi}{\bar{c}} \\
\text { ठ̀ं }\end{array}$ & 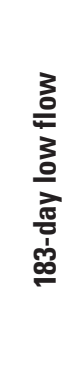 & 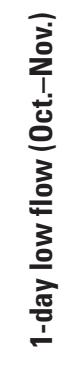 & 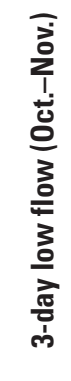 & 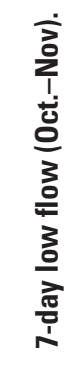 & 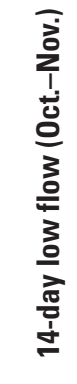 & 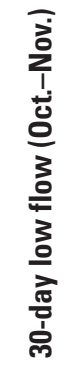 & 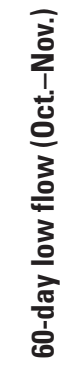 & 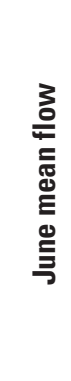 & 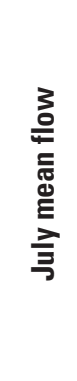 & 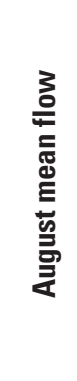 & 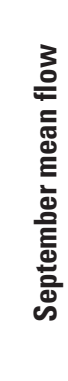 \\
\hline 06774000 & $\begin{array}{l}\text { Platte River near } \\
\text { Duncan, Nebr' }{ }^{1} \text {. }\end{array}$ & $1961-2011$ & I & I & I & I & I & I & I & I & I & I & I & I & I & I & I & I & I & I & $\mathrm{P}$ & I \\
\hline 06796000 & $\begin{array}{l}\text { Platte River at North } \\
\text { Bend, Nebr. }{ }^{1}\end{array}$ & $1961-2011$ & I & I & I & I & I & $\mathrm{P}$ & $\mathrm{P}$ & $\mathrm{P}$ & I & I & I & I & I & I & I & I & I & I & $\mathrm{P}$ & I \\
\hline 06798500 & $\begin{array}{l}\text { Elkhorn River at } \\
\text { Neligh, Nebr. }^{2}\end{array}$ & $1961-2011$ & $\mathrm{P}$ & I & I & I & I & I & I & I & I & I & I & I & I & I & I & I & I & I & I & I \\
\hline 06799500 & $\begin{array}{r}\text { Logan Creek near } \\
\text { Uehling, Nebr. }{ }^{1}\end{array}$ & $1961-2011$ & $\mathrm{P}$ & $\mathrm{P}$ & $\mathrm{P}$ & $\mathrm{P}$ & $\mathrm{P}$ & $\mathrm{P}$ & $\mathrm{P}$ & $\mathrm{P}$ & $\mathrm{P}$ & $\mathrm{P}$ & $\mathrm{P}$ & $\mathrm{P}$ & $\mathrm{P}$ & $\mathrm{P}$ & $\mathrm{P}$ & $\mathrm{P}$ & $\mathrm{P}$ & $\mathrm{P}$ & $\mathrm{P}$ & $\mathrm{P}$ \\
\hline 06800000 & $\begin{array}{l}\text { Maple Creek near } \\
\text { Nickerson, Nebr. }{ }^{1}\end{array}$ & $1961-2011$ & I & $\mathrm{P}$ & $\mathrm{P}$ & $\mathrm{P}$ & $\mathrm{P}$ & $\mathrm{P}$ & $\mathrm{P}$ & $\mathrm{P}$ & $\mathrm{P}$ & $\mathrm{P}$ & $\mathrm{P}$ & $\mathrm{P}$ & $\mathrm{P}$ & $\mathrm{P}$ & $\mathrm{P}$ & $\mathrm{P}$ & I & $\mathrm{P}$ & $\mathrm{P}$ & $\mathrm{P}$ \\
\hline 06800500 & $\begin{array}{l}\text { Elkhorn River at } \\
\text { Waterloo, Nebr. }{ }^{1}\end{array}$ & $1961-2011$ & $\mathrm{P}$ & $\mathrm{P}$ & $\mathrm{P}$ & $\mathrm{P}$ & $\mathrm{P}$ & $\mathrm{P}$ & $\mathrm{P}$ & $\mathrm{P}$ & $\mathrm{P}$ & $\mathrm{P}$ & $\mathrm{P}$ & $\mathrm{P}$ & $\mathrm{P}$ & $\mathrm{P}$ & $\mathrm{P}$ & $\mathrm{P}$ & $\mathrm{P}$ & $\mathrm{P}$ & $\mathrm{P}$ & $\mathrm{P}$ \\
\hline 06803555 & $\begin{array}{l}\text { Salt Creek at } \\
\text { Greenwood, } \\
\text { Nebr. }{ }^{1}\end{array}$ & $1961-2011$ & I & $\mathrm{P}$ & $\mathrm{P}$ & $\mathrm{P}$ & $\mathrm{P}$ & $\mathrm{P}$ & $\mathrm{P}$ & $\mathrm{P}$ & $\mathrm{P}$ & $\mathrm{P}$ & $\mathrm{P}$ & $\mathrm{P}$ & $\mathrm{P}$ & $\mathrm{P}$ & $\mathrm{P}$ & $\mathrm{P}$ & I & I & $\mathrm{P}$ & I \\
\hline 06805500 & $\begin{array}{l}\text { Platte River at } \\
\quad \text { Louisville, Nebr. }{ }^{1}\end{array}$ & $1961-2011$ & I & $\mathrm{P}$ & $\mathrm{P}$ & $\mathrm{P}$ & $\mathrm{P}$ & I & I & $\mathrm{P}$ & I & $\mathrm{P}$ & $\mathrm{P}$ & $\mathrm{P}$ & $\mathrm{P}$ & $\mathrm{P}$ & $\mathrm{P}$ & $\mathrm{P}$ & I & I & $\mathrm{P}$ & I \\
\hline
\end{tabular}

${ }^{1}$ Streamgage data from the U.S. Geological Survey.

${ }^{2}$ Streamgage operated by the Nebraska Department of Natural Resources. 
Table 4. Comparison of streamflow trends for the complete period of record with trends for 1961-2011 at selected sites in the Elkhorn River, Salt Creek, and Platte River Basins, Nebraska.

[Significant trends had probability values less than or equal to 0.05 ; red shading indicates the period of record had a significant trend but 1961-2011 indicated an insignificant trend; green shading indicates the period of record had an insignificant trend but 1961-2011 indicated a significant positive trend; Oct., October; Nov., November; Nebr., Nebraska; I, insignificant trend; P, significant positive trend; X-Y, trend for period of record analysis (X) and 1961-2011 analysis (Y)]

\begin{tabular}{|c|c|c|c|c|c|c|c|c|c|c|c|c|c|c|c|c|c|c|c|c|c|c|}
\hline \multirow{2}{*}{\multicolumn{2}{|c|}{$\begin{array}{l}\text { U.S. Geological Survey and } \\
\text { Nebraska Department of Natural } \\
\text { Resources streamgages }\end{array}$}} & \multirow[b]{2}{*}{$\begin{array}{l}\text { Period } \\
\text { of record } \\
\text { analyzed }\end{array}$} & \multirow{2}{*}{\multicolumn{2}{|c|}{ 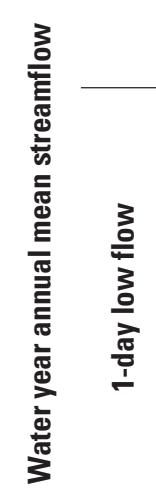 }} & \multirow[b]{2}{*}{ 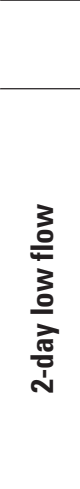 } & \multicolumn{7}{|c|}{ Climatic year annual low flows } & \multicolumn{6}{|c|}{ Fall low flows } & \multicolumn{4}{|c|}{$\begin{array}{c}\text { Growing season } \\
\text { monthly mean flows }\end{array}$} \\
\hline & & & & & & 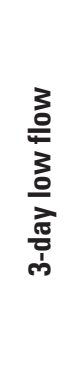 & $\begin{array}{l}3 \\
\text { o } \\
\frac{3}{3} \\
\frac{0}{2} \\
\frac{\pi}{i} \\
i\end{array}$ & $\begin{array}{l}3 \\
0 \\
\frac{3}{4} \\
3 \\
\frac{0}{2} \\
\frac{\pi}{0} \\
\frac{1}{1}\end{array}$ & 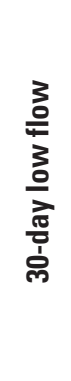 & 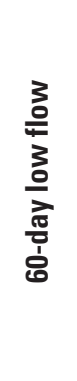 & 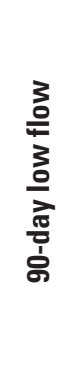 & 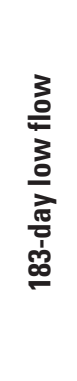 & 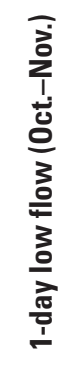 & 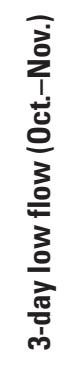 & 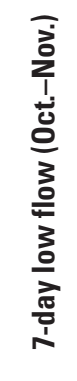 & 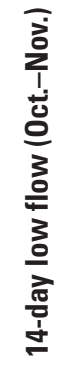 & 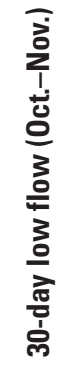 & 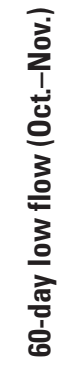 & 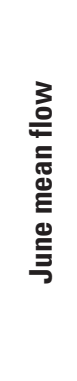 & 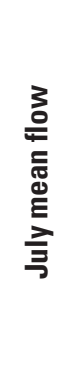 & 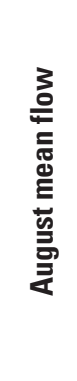 & 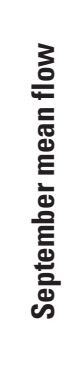 \\
\hline 06774000 & $\begin{array}{l}\text { Platte River near } \\
\text { Duncan, Nebr. }{ }^{1}\end{array}$ & 1929-2011 & $\mathrm{I}-\mathrm{I}$ & $\mathrm{P}-\mathrm{I}$ & $\mathrm{P}-\mathrm{I}$ & $\mathrm{P}-\mathrm{I}$ & $\mathrm{P}-\mathrm{I}$ & $\mathrm{P}-\mathrm{I}$ & $\mathrm{P}-\mathrm{I}$ & $\mathrm{P}-\mathrm{I}$ & $\mathrm{P}-\mathrm{I}$ & $\mathrm{P}-\mathrm{I}$ & $\mathrm{P}-\mathrm{I}$ & $\mathrm{P}-\mathrm{I}$ & $\mathrm{P}-\mathrm{I}$ & $\mathrm{P}-\mathrm{I}$ & $\mathrm{P}-\mathrm{I}$ & $\mathrm{P}-\mathrm{I}$ & $\mathrm{I}-\mathrm{I}$ & $\mathrm{I}-\mathrm{I}$ & $\mathrm{P}-\mathrm{P}$ & $\mathrm{I}-\mathrm{I}$ \\
\hline 06796000 & $\begin{array}{l}\text { Platte River at North } \\
\text { Bend, Nebr. }{ }^{1}\end{array}$ & $1950-2011$ & $\mathrm{I}-\mathrm{I}$ & $\mathrm{I}-\mathrm{I}$ & $\mathrm{I}-\mathrm{I}$ & $\mathrm{I}-\mathrm{I}$ & $\mathrm{I}-\mathrm{I}$ & $\mathrm{I}-\mathrm{P}$ & $\mathrm{P}-\mathrm{P}$ & $\mathrm{P}-\mathrm{P}$ & $\mathrm{I}-\mathrm{I}$ & $\mathrm{P}-\mathrm{I}$ & $\mathrm{I}-\mathrm{I}$ & $\mathrm{P}-\mathrm{I}$ & $\mathrm{P}-\mathrm{I}$ & $\mathrm{P}-\mathrm{I}$ & $\mathrm{P}-\mathrm{I}$ & $\mathrm{P}-\mathrm{I}$ & $\mathrm{I}-\mathrm{I}$ & $\mathrm{I}-\mathrm{I}$ & $\mathrm{P}-\mathrm{P}$ & $\mathrm{I}-\mathrm{I}$ \\
\hline 06798500 & $\begin{array}{l}\text { Elkhorn River at } \\
\text { Neligh, Nebr. }{ }^{2}\end{array}$ & $1931-2011$ & $\mathrm{P}-\mathrm{P}$ & $\mathrm{P}-\mathrm{I}$ & $\mathrm{P}-\mathrm{I}$ & $\mathrm{P}-\mathrm{I}$ & $\mathrm{P}-\mathrm{I}$ & $\mathrm{P}-\mathrm{I}$ & $\mathrm{P}-\mathrm{I}$ & $\mathrm{P}-\mathrm{I}$ & $\mathrm{P}-\mathrm{I}$ & $\mathrm{P}-\mathrm{I}$ & $\mathrm{P}-\mathrm{I}$ & $\mathrm{P}-\mathrm{I}$ & $\mathrm{P}-\mathrm{I}$ & $\mathrm{P}-\mathrm{I}$ & $\mathrm{P}-\mathrm{I}$ & $\mathrm{P}-\mathrm{I}$ & $\mathrm{I}-\mathrm{I}$ & $\mathrm{I}-\mathrm{I}$ & $\mathrm{I}-\mathrm{I}$ & $\mathrm{I}-\mathrm{I}$ \\
\hline 06799500 & $\begin{array}{l}\text { Logan Creek near } \\
\text { Uehling, Nebr. }{ }^{1}\end{array}$ & $1942-2011$ & $\mathrm{P}-\mathrm{P}$ & $\mathrm{P}-\mathrm{P}$ & $\mathrm{P}-\mathrm{P}$ & P-P & P-P & P-P & $\mathrm{P}-\mathrm{P}$ & $\mathrm{P}-\mathrm{P}$ & $\mathrm{P}-\mathrm{P}$ & $\mathrm{P}-\mathrm{P}$ & $\mathrm{P}-\mathrm{P}$ & P-P & $\mathrm{P}-\mathrm{P}$ & $\mathrm{P}-\mathrm{P}$ & $\mathrm{P}-\mathrm{P}$ & $\mathrm{P}-\mathrm{P}$ & $\mathrm{P}-\mathrm{P}$ & $\mathrm{P}-\mathrm{P}$ & $\mathrm{P}-\mathrm{P}$ & P-P \\
\hline 06800000 & $\begin{array}{l}\text { Maple Creek near } \\
\text { Nickerson, Nebr. }{ }^{1}\end{array}$ & $1952-2011$ & $\mathrm{P}-\mathrm{I}$ & $\mathrm{P}-\mathrm{P}$ & P-P & $\mathrm{P}-\mathrm{P}$ & P-P & P-P & $\mathrm{P}-\mathrm{P}$ & $\mathrm{P}-\mathrm{P}$ & $\mathrm{P}-\mathrm{P}$ & $\mathrm{P}-\mathrm{P}$ & $\mathrm{P}-\mathrm{P}$ & $\mathrm{P}-\mathrm{P}$ & P-P & $\mathrm{P}-\mathrm{P}$ & $\mathrm{P}-\mathrm{P}$ & $\mathrm{P}-\mathrm{P}$ & $\mathrm{I}-\mathrm{I}$ & $\mathrm{P}-\mathrm{P}$ & $\mathrm{P}-\mathrm{P}$ & P-P \\
\hline 06800500 & $\begin{array}{l}\text { Elkhorn River at } \\
\text { Waterloo, Nebr. }{ }^{1}\end{array}$ & 1929-2011 & $\mathrm{P}-\mathrm{P}$ & $\mathrm{P}-\mathrm{P}$ & P-P & $\mathrm{P}-\mathrm{P}$ & P-P & $\mathrm{P}-\mathrm{P}$ & P-P & $\mathrm{P}-\mathrm{P}$ & $\mathrm{P}-\mathrm{P}$ & $\mathrm{P}-\mathrm{P}$ & $\mathrm{P}-\mathrm{P}$ & P-P & P-P & $\mathrm{P}-\mathrm{P}$ & $\mathrm{P}-\mathrm{P}$ & $\mathrm{P}-\mathrm{P}$ & $\mathrm{P}-\mathrm{P}$ & $\mathrm{P}-\mathrm{P}$ & $\mathrm{P}-\mathrm{P}$ & P-P \\
\hline 06803555 & $\begin{array}{l}\text { Salt Creek at } \\
\text { Greenwood, } \\
\text { Nebr. }{ }^{1}\end{array}$ & $1952-2011$ & $\mathrm{P}-\mathrm{I}$ & $\mathrm{P}-\mathrm{P}$ & P-P & $\mathrm{P}-\mathrm{P}$ & P-P & P-P & P-P & $\mathrm{P}-\mathrm{P}$ & $\mathrm{P}-\mathrm{P}$ & $\mathrm{P}-\mathrm{P}$ & $\mathrm{P}-\mathrm{P}$ & $\mathrm{P}-\mathrm{P}$ & P-P & $\mathrm{P}-\mathrm{P}$ & $\mathrm{P}-\mathrm{P}$ & $\mathrm{P}-\mathrm{P}$ & $\mathrm{I}-\mathrm{I}$ & $\mathrm{I}-\mathrm{I}$ & $\mathrm{P}-\mathrm{P}$ & $\mathrm{I}-\mathrm{I}$ \\
\hline 06805500 & $\begin{array}{l}\text { Platte River at } \\
\quad \text { Louisville, Nebr. }{ }^{1}\end{array}$ & $1954-2011$ & $\mathrm{P}-\mathrm{I}$ & $\mathrm{P}-\mathrm{P}$ & P-P & $\mathrm{P}-\mathrm{P}$ & $\mathrm{P}-\mathrm{P}$ & $\mathrm{P}-\mathrm{I}$ & $\mathrm{P}-\mathrm{I}$ & $\mathrm{P}-\mathrm{P}$ & $\mathrm{P}-\mathrm{I}$ & $\mathrm{P}-\mathrm{P}$ & $\mathrm{P}-\mathrm{P}$ & $\mathrm{P}-\mathrm{P}$ & P-P & $\mathrm{P}-\mathrm{P}$ & $\mathrm{P}-\mathrm{P}$ & $\mathrm{P}-\mathrm{P}$ & $\mathrm{I}-\mathrm{I}$ & $\mathrm{I}-\mathrm{I}$ & $\mathrm{P}-\mathrm{P}$ & $\mathrm{I}-\mathrm{I}$ \\
\hline
\end{tabular}

1Streamgage data from the U.S. Geological Survey.

2Streamgage operated by U.S. Geological Survey from water years 1930 to 1993, maintained by Nebraska Department of Natural Resources from water years 1994 to 2019. 
Table 5. Effect of beginning year on trends in streamflow at selected sites in the Elkhorn River, Salt Creek, and Platte River Basins, Nebraska.

[Period of analysis beginning in year indicated through 2011; low-flow periods use the climatic water year; annual mean flow periods are in water years; significant trends are shaded; Nebr., Nebraska; I, insignificant trend with probability $(p)$ value greater than $0.05 ; \mathrm{S}$, significant trend with $p$-value less than or equal to 0.05 ]

Year

\section{Period}

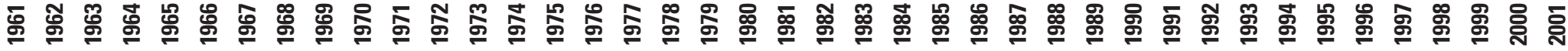

\section{Platte River near Duncan, Nebr. (U.S. Geological Survey station 06774000)}

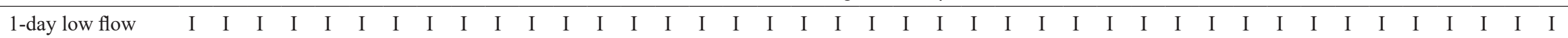

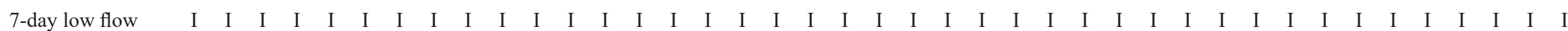

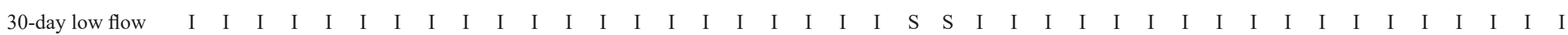

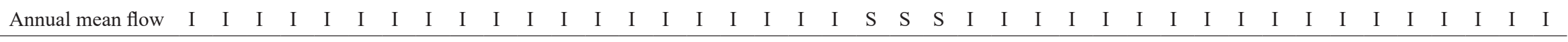
Platte River at North Bend, Nebr. (U.S. Geological Survey station 06796000)

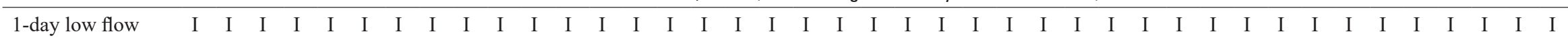

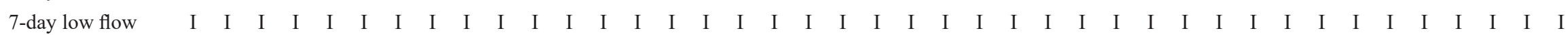

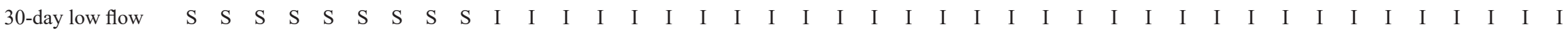

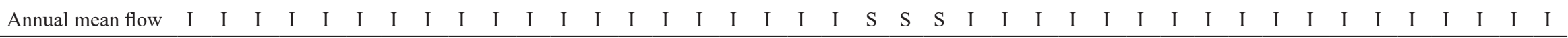
Elkhorn River at Neligh, Nebr. (Nebraska Department of Natural Resources streamgage; U.S. Geological Survey station 06798500)1

$\begin{array}{llllllllllllllllllllllllllllllllllllllllllllllllllllll}\text { 1-day low flow } & \mathrm{S} & \mathrm{S} & \mathrm{S} & \mathrm{S} & \mathrm{S} & \mathrm{S} & \mathrm{S} & \mathrm{S} & \mathrm{S} & \mathrm{S} & \mathrm{S} & \mathrm{S} & \mathrm{S} & \mathrm{S} & \mathrm{S} & \mathrm{S} & \mathrm{S} & \mathrm{S} & \mathrm{S} & \mathrm{S} & \mathrm{S} & \mathrm{S} & \mathrm{S} & \mathrm{S} & \mathrm{S} & \mathrm{S} & \mathrm{S} & \mathrm{S} & \mathrm{S} & \mathrm{S} & \mathrm{S} & \mathrm{S} & \mathrm{S} & \mathrm{S} & \mathrm{I} & \mathrm{I} & \mathrm{I} & \mathrm{I} & \mathrm{I} & \mathrm{I} & \mathrm{I}\end{array}$

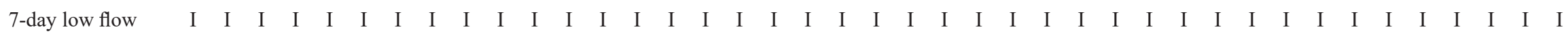

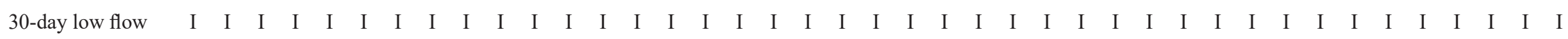

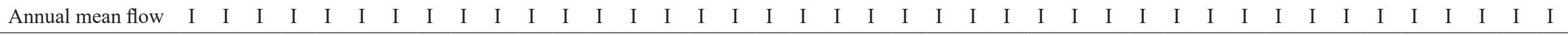
Logan Creek near Uehling, Nebr. (U.S. Geological Survey station 06799500)

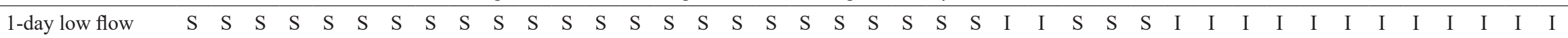

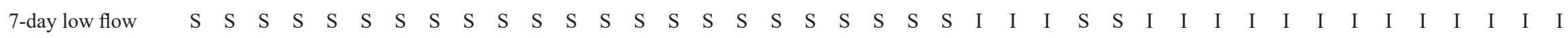

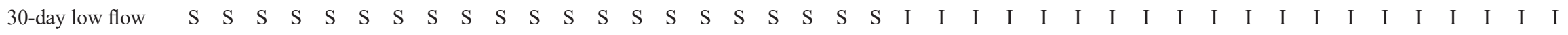

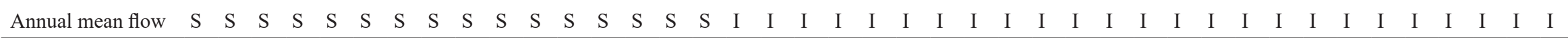

Maple Creek near Nickerson, Nebr. (U.S. Geological Survey station 06800000)

$\begin{array}{lllllllllllllllllllllllllllllllllllllllllllllllllllllllll}\text { 1-day low flow } & \text { S } & \text { S } & \text { S } & \text { S } & \text { S } & \text { S } & \text { S } & \text { S } & \text { S } & \text { S } & \text { S } & \text { S } & \text { S } & \text { S } & \text { S } & \text { S } & \text { S } & \text { I } & \text { I } & \text { I } & \text { I } & \text { I } & \text { I } & \text { I } & \text { I } & \text { I } & \text { I } & \text { I } & \text { I } & \text { I } & \text { I } & \text { I } & \text { I } & \text { I } & \text { I } & \text { I } & \text { I } & \text { I } & \text { I } & \text { I } & \text { I }\end{array}$

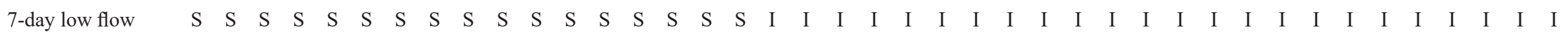

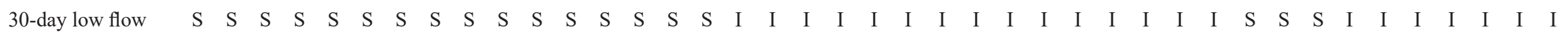

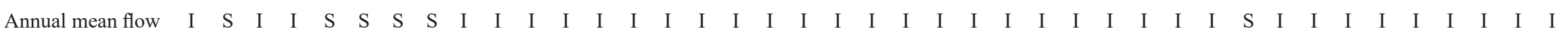


Table 5. Effect of beginning year on trends in streamflow at selected sites in the Elkhorn River, Salt Creek, and Platte River Basins, Nebraska.-Continued.

[Period of analysis beginning in year indicated through 2011; low-flow periods use the climatic water year; annual mean flow periods are in water years; significant trends are shaded; Nebr., Nebraska; I, insignificant trend with probability $(p)$ value greater than $0.05 ; \mathrm{S}$, significant trend with $p$-value less than or equal to 0.05$]$

Year

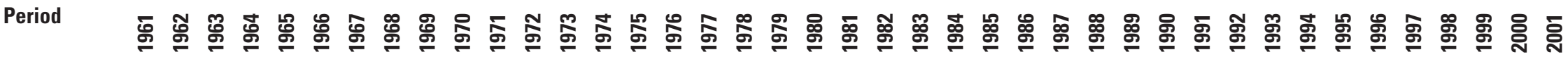
Elkhorn River at Waterloo, Nebr. (U.S. Geological Survey station 06800500)

\begin{tabular}{|c|c|c|c|c|c|c|c|c|c|c|c|c|c|c|c|c|c|c|c|c|c|c|c|c|c|c|c|c|c|c|c|c|c|c|c|c|c|c|c|c|c|}
\hline 1-day low flow & $\mathrm{S}$ & $\mathrm{S}$ & $\mathrm{S}$ & $\mathrm{S}$ & $\mathrm{S}$ & $\mathrm{S}$ & S & $\mathrm{S}$ & $\mathrm{S}$ & S & $\mathrm{S}$ & $\mathrm{S}$ & S & $\mathrm{S}$ & $\mathrm{S}$ & $\mathrm{S}$ & I & I & I & I & I & I & I & I & I & I & I & I & I & I & I & I & I & I & I & I & I & I & I & I & I \\
\hline 7-day low flow & $\mathrm{S}$ & $\mathrm{S}$ & $\mathrm{S}$ & $\mathrm{S}$ & $\mathrm{S}$ & $\mathrm{S}$ & $\mathrm{S}$ & $\mathrm{S}$ & $\mathrm{S}$ & $\mathrm{S}$ & $\mathrm{S}$ & $\mathrm{S}$ & $\mathrm{S}$ & $\mathrm{S}$ & $\mathrm{S}$ & $\mathrm{S}$ & I & I & I & I & I & I & I & I & I & I & I & I & I & I & I & I & I & I & I & I & I & I & I & I & I \\
\hline 30-day low flow & $\mathrm{S}$ & $\mathrm{S}$ & $\mathrm{S}$ & $\mathrm{S}$ & $\mathrm{S}$ & $\mathrm{S}$ & S & $\mathrm{S}$ & $\mathrm{S}$ & $\mathrm{S}$ & $\mathrm{S}$ & $\mathrm{S}$ & $\mathrm{S}$ & $\mathrm{S}$ & $\mathrm{S}$ & $\mathrm{S}$ & I & I & I & I & I & I & I & I & I & I & I & I & I & I & I & I & I & I & I & I & I & I & I & I & I \\
\hline Annual mean flow & I & $\mathrm{S}$ & I & I & $\mathrm{S}$ & $\mathrm{S}$ & $\mathrm{S}$ & $\mathrm{S}$ & I & I & I & I & I & I & I & I & I & I & I & I & I & I & I & I & I & I & I & I & I & I & I & $\mathrm{S}$ & I & I & I & I & I & I & I & I & I \\
\hline \multicolumn{42}{|c|}{ Salt Creek at Greenwood, Nebr. (U.S. Geological Survey station 06803555) } \\
\hline 1-day low flow & $\mathrm{S}$ & $\mathrm{S}$ & $\mathrm{S}$ & $\mathrm{S}$ & $\mathrm{S}$ & $\mathrm{S}$ & $\mathrm{S}$ & $\mathrm{S}$ & I & I & I & I & I & I & I & I & I & I & I & I & I & I & I & I & I & I & I & I & I & I & I & I & I & I & I & I & I & I & I & I & I \\
\hline 7-day low flow & $\mathrm{S}$ & $\mathrm{S}$ & $\mathrm{S}$ & $\mathrm{S}$ & $\mathrm{S}$ & $\mathrm{S}$ & $\mathrm{S}$ & I & I & I & I & I & I & I & I & I & I & I & I & I & I & I & I & I & I & I & I & I & I & I & I & I & I & I & I & I & I & I & I & I & I \\
\hline 30-day low flow & $\mathrm{S}$ & $\mathrm{S}$ & $\mathrm{S}$ & $\mathrm{S}$ & $\mathrm{S}$ & $\mathrm{S}$ & $\mathrm{S}$ & I & I & I & I & I & I & I & I & I & I & I & I & I & I & I & I & I & I & I & I & I & I & I & I & I & I & I & I & I & I & I & I & I & I \\
\hline Annual mean flow & I & I & I & I & I & I & I & I & I & I & I & I & I & I & I & I & I & I & I & I & I & I & I & I & I & I & I & I & I & I & I & I & I & I & I & I & I & I & I & I & I \\
\hline \multicolumn{42}{|c|}{ Platte River at Louisville, Nebr. (U.S. Geological Survey station 06805500) } \\
\hline 1-day low flow & $\mathrm{S}$ & $\mathrm{S}$ & $\mathrm{S}$ & $\mathrm{S}$ & $\mathrm{S}$ & $\mathrm{S}$ & $\mathrm{S}$ & $\mathrm{S}$ & $\mathrm{S}$ & $\mathrm{S}$ & $\mathrm{S}$ & $\mathrm{S}$ & $\mathrm{S}$ & $\mathrm{S}$ & I & I & I & I & I & I & I & I & I & I & I & I & I & I & I & I & I & I & I & I & I & I & I & I & I & I & I \\
\hline 7-day low flow & $\mathrm{S}$ & $\mathrm{S}$ & $\mathrm{S}$ & $\mathrm{S}$ & $\mathrm{S}$ & $\mathrm{S}$ & $\mathrm{S}$ & $\mathrm{S}$ & $\mathrm{S}$ & $\mathrm{S}$ & $\mathrm{S}$ & $\mathrm{S}$ & $\mathrm{S}$ & $\mathrm{S}$ & I & I & I & I & I & I & I & I & I & I & I & I & I & I & I & I & I & I & I & I & I & I & I & I & I & I & I \\
\hline 30-day low flow & I & I & $\mathrm{S}$ & I & I & I & $\mathrm{S}$ & I & I & I & I & I & I & I & I & I & I & I & I & I & I & I & I & I & I & I & I & I & I & I & I & I & I & I & I & I & I & I & I & I & I \\
\hline Annual mean flow & $\mathrm{I}$ & I & I & I & I & I & I & I & $\mathrm{I}$ & I & I & $\mathrm{I}$ & I & $\mathrm{I}$ & $\mathrm{I}$ & I & I & I & I & I & I & I & I & I & I & I & I & I & I & I & I & I & I & I & I & I & I & I & I & I & I \\
\hline
\end{tabular}

${ }^{1}$ Streamgage operated by U.S. Geological Survey from water years 1930 to 1993, maintained by Nebraska Department of Natural Resources from water years 1994 to 2019. 


\section{Precipitation Trends}

Precipitation was examined as a primary cause for streamflow trends for the period 1961-2011. Composite precipitation data series upstream from each of the four streamgages in the Elkhorn River Basin (Elkhorn River at Neligh, Nebr.; Logan Creek near Uehling, Nebr.; Maple Creek near Nickerson, Nebr.; and Elkhorn River at Waterloo, Nebr.) were synthesized by computing an area-weighted mean of volumes reported from precipitation stations in and around the study area and were summarized for each month or year (fig. 4). Of the four sites, only the Elkhorn River at Neligh, Nebr., streamgage indicated a significant increase in annual precipitation (table 6). When the data were separated into monthly precipitation, few trends were indicated; only 4 of the 48 site-month combinations indicated significant trends (table 6).

For the four streamgages in the Elkhorn River Basin, relations between precipitation and streamflow were examined on an annual and monthly basis using linear regression. Linear models were developed in the R statistical software (Venables and others, 2017) between the annual-composited precipitation and a logarithmic transformation of annual mean streamflow (fig. 5). Similarly, linear models compared the monthly composited precipitation time series against the logarithmically transformed streamflow for the same month over the 1961-2011 period (fig. 6). In general, the goodnessof-fit values for the linear relations were poor and coefficient

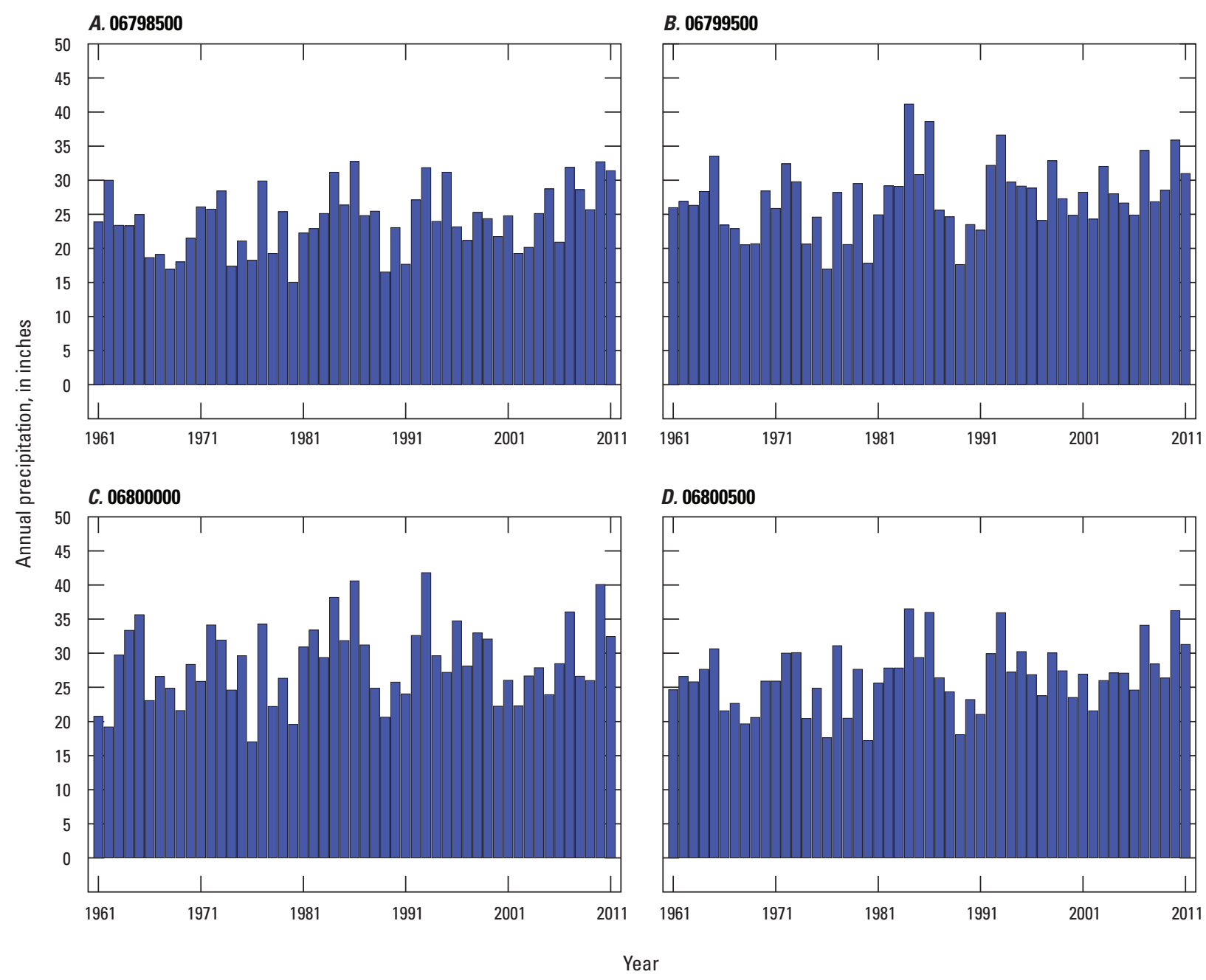

EXPLANATION

Observed, annual

Figure 4. Annual water year precipitation composited for the areas upstream from four streamgages, 1961-2011. $A$, Nebraska Department of Natural Resources Elkhorn River at Neligh, Nebraska (station 06798500); $B$, U.S. Geological Survey Logan Creek near Uehling, Nebr. (station 06799500); C, U.S. Geological Survey Maple Creek near Nickerson, Nebr. (station 06800000); D, U.S. Geological Survey Elkhorn River at Waterloo, Nebr. (station 06800500). 
Table 6. Monthly and annual trends in precipitation composited for the areas upstream from selected streamgages in the Elkhorn River Basin, Nebraska, 1961-2011.

[The probability $(p)$ value is shown in parentheses; P, significant positive (upward) trend with a $p$-value less than or equal to 0.05 ; I, insignificant trend with a $p$-value greater than 0.05$]$

\begin{tabular}{|c|c|c|c|c|}
\hline \multirow[b]{2}{*}{ Period } & \multicolumn{4}{|c|}{ U.S. Geological Survey streamgages and station numbers } \\
\hline & $\begin{array}{c}\text { Elkhorn River at Waterloo, } \\
\text { Nebr., station } 06798500\end{array}$ & $\begin{array}{l}\text { Logan Creek near Uehling, } \\
\text { Nebr., station } 06799500\end{array}$ & $\begin{array}{c}\text { Maple Creek near Nickerson, } \\
\text { Nebr., station } 06800000\end{array}$ & $\begin{array}{c}\text { Elkhorn River at Waterloo, } \\
\text { Nebr., station } 06800500\end{array}$ \\
\hline January & $\mathrm{I}(0.26)$ & $\mathrm{P}(0.04)$ & $\mathrm{I}(0.05)$ & $\mathrm{I}(0.17)$ \\
\hline February & $\mathrm{I}(0.24)$ & $\mathrm{I}(0.40)$ & $\mathrm{I}(0.54)$ & $\mathrm{I}(0.31)$ \\
\hline May & $\mathrm{I}(0.10)$ & I $(0.64)$ & $\mathrm{I}(0.54)$ & $\mathrm{I}(0.40)$ \\
\hline June & $\mathrm{I}(0.58)$ & I $(0.69)$ & I $(0.59)$ & I (1.00) \\
\hline July & $\mathrm{I}(0.44)$ & $\mathrm{I}(0.84)$ & $\mathrm{I}(0.94)$ & $\mathrm{I}(0.57)$ \\
\hline August & $\mathrm{I}(0.15)$ & $\mathrm{I}(0.70)$ & $\mathrm{I}(0.81)$ & $\mathrm{I}(0.24)$ \\
\hline December & $\mathrm{I}(0.23)$ & $\mathrm{I}(0.31)$ & I (0.79) & I (0.65) \\
\hline
\end{tabular}

${ }^{1}$ Computation based on water year. A water year begins October 1 of the previous calendar year and ends September 30 of the year of interest. Thus, the water year ending September 30, 2011, is called the "2011 water year."

of determination $\left(R^{2}\right)$ values were 0.10 or less in 50 percent of the relations. The relation with the overall highest $R^{2}$ value was for July precipitation and streamflow at the Maple Creek near Nickerson, Nebr., streamgage with an $R^{2}$ value of 0.58 . For each of the remaining three streamgages (Logan Creek near Uehling, Nebr.; Elkhorn River at Neligh, Nebr.; and Elkhorn River at Waterloo, Nebr.), the highest goodness-of-fit values were for the June precipitation-streamflow relations $\left(R^{2}\right.$ values of $0.50,0.20$, and 0.42 , respectively).

\section{Residual Streamflow Trends}

Though the relation of streamflow to precipitation is not well constrained, it is still desirable to remove the effect of precipitation on streamflow to identify the streamflow trends resulting from other factors. The linear models were used to remove the effect of precipitation from the flow data. For each precipitation time series (annual and for each calendar month), the precipitation was used as an input to the linear models to calculate a predicted streamflow; then, the predicted streamflow was subtracted from the observed streamflow to compute the residual streamflow. The Kendall's tau test was then applied to the resulting times series of residual values. If the trend in the residual streamflow is significant and positive, it implies that something other than precipitation is causing that increase. Significant increases were detected for the annual mean streamflow residuals for the Logan Creek near Uehling, Nebr.; Maple Creek near Nickerson, Nebr.; and Elkhorn River at Waterloo, Nebr., streamgages. In general, monthly streamflow residuals indicated positive trends, with a greater frequency of those trends at the Logan Creek near Uehling, Nebr.; Maple Creek near Nickerson, Nebr.; and Elkhorn River at Waterloo, Nebr., streamgages than the Elkhorn River at Neligh, Nebr., streamgage (table 7). Only one significant increase in annual precipitation above the streamgages and the frequent detection of significant increases in streamflow after removing the effect of precipitation indicate that other factors besides precipitation may have played a role in the positive trends in low-flow periods in the lower Elkhorn River and its tributaries. 

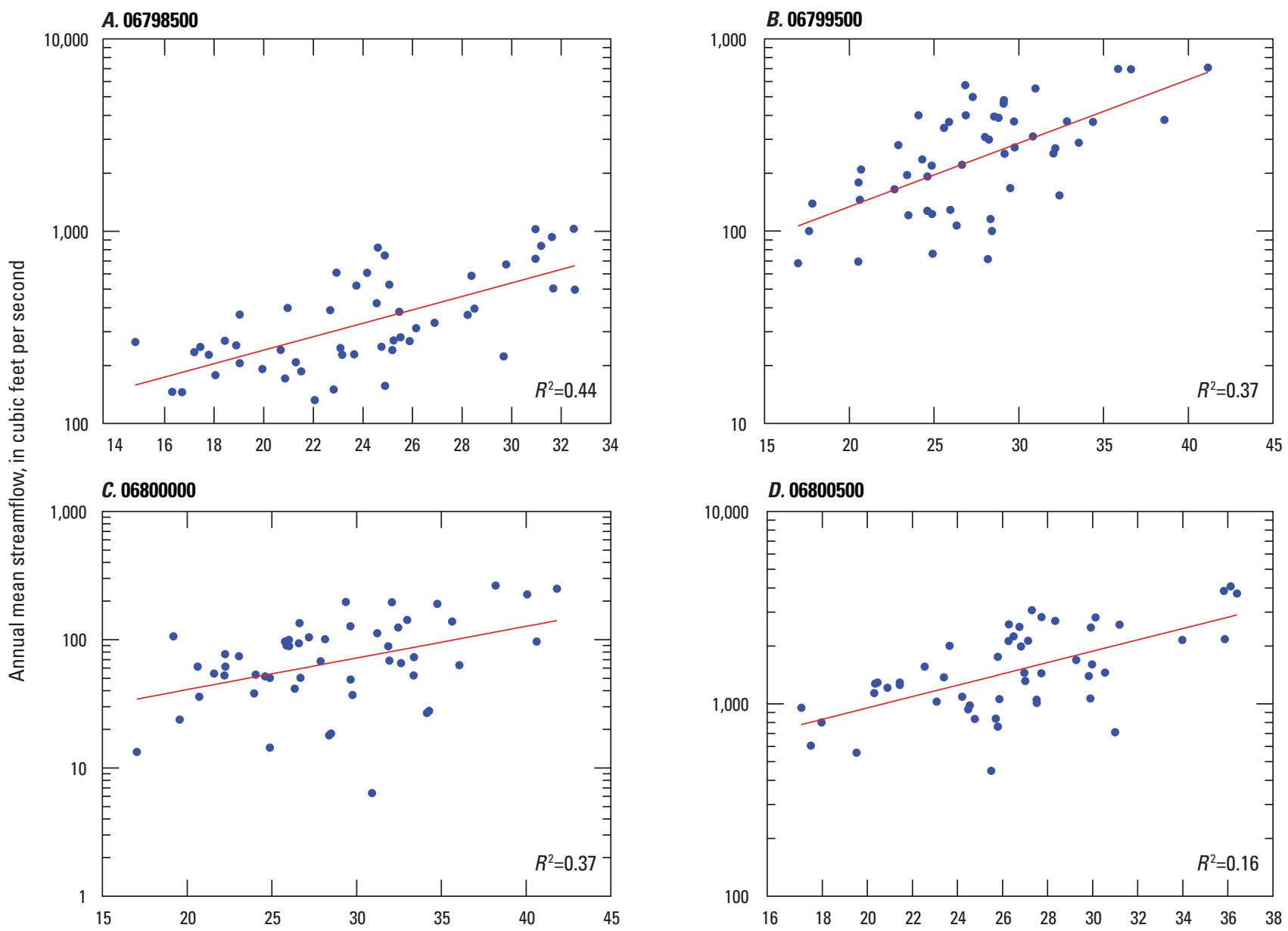

Precipitation, in inches

\section{EXPLANATION}

$\left[R^{2}\right.$, coefficient of determination]

- Observed, annual

- Linear fit using a logarithmic transformation of streamflow

Figure 5. Plots of annual-composited precipitation upstream from the streamgage and annual mean streamflow for four streamgages, 1961-2011. A, Nebraska Department of Natural Resources Elkhorn River at Neligh, Nebraska (station 06798500); B, U.S. Geological Survey Logan Creek near Uehling, Nebr. (station 06799500); C, U.S. Geological Survey Maple Creek near Nickerson, Nebr. (station 06800000); D, U.S. Geological Survey Elkhorn River at Waterloo, Nebr. (station 06800500). 

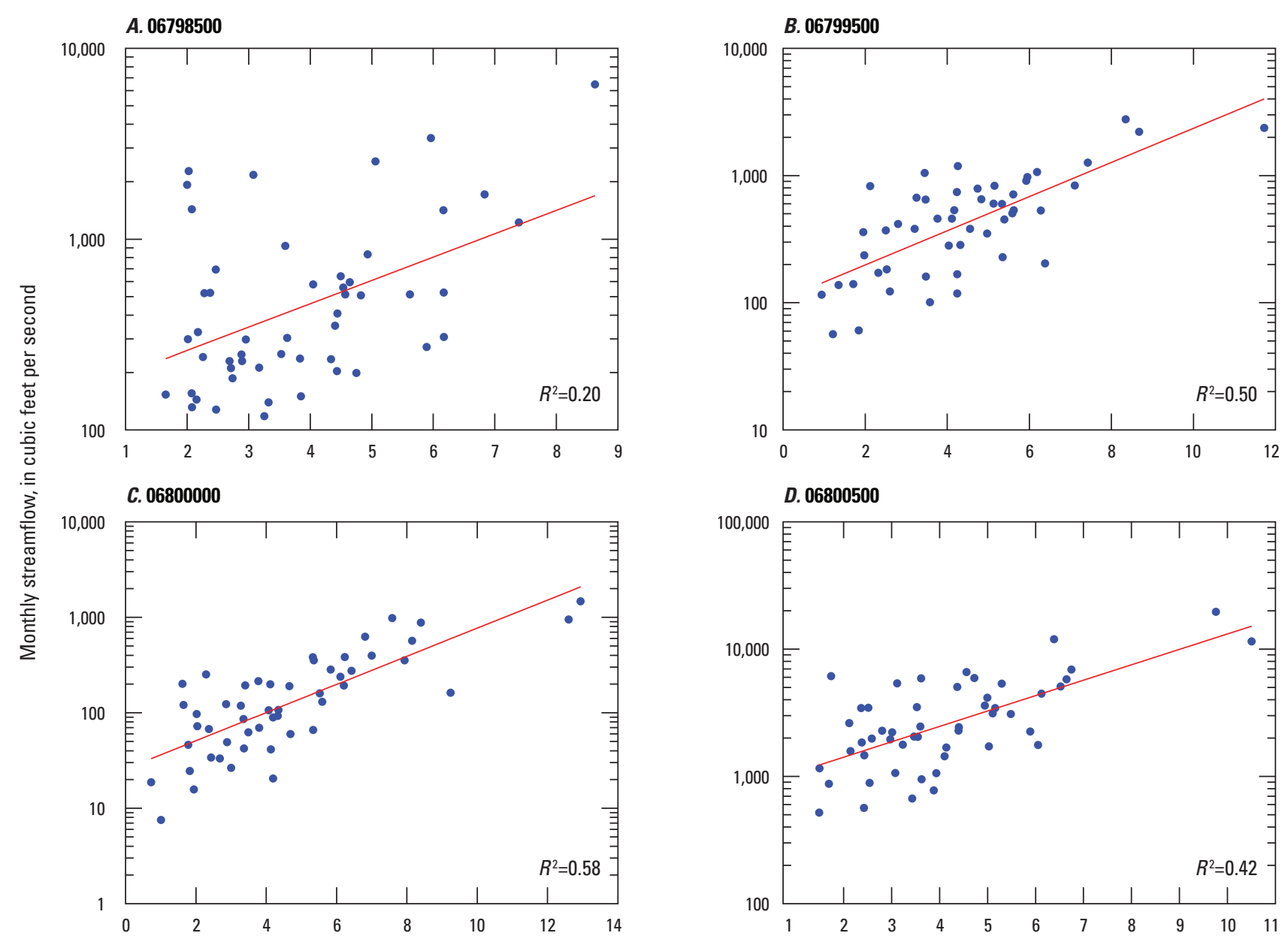

Precipitation, in inches

EXPLANATION

$\left[R^{2}\right.$, coefficient of determination]

- Observed, June

— Linear fit using a logarithmic transformation of streamflow

Figure 6. Plots of June monthly composited precipitation upgradient of the streamgage and mean June streamflow for four streamgages, 1961-2011. A, Nebraska Department of Natural Resources Elkhorn River at Neligh, Nebraska (station 06798500); $B$, U.S. Geological Survey Logan Creek near Uehling, Nebr. (station 06799500); C, U.S. Geological Survey Maple Creek near Nickerson, Nebr. (station 06800000); D, U.S. Geological Survey Elkhorn River at Waterloo, Nebr. (station 06800500). 
Table 7. Monthly and annual trends in precipitation-adjusted streamflow residuals for selected streamgages in the Elkhorn River Basin, Nebraska, 1961-2011.

[The probability $(p)$ value is shown in parentheses; P, significant positive (upward) trend with a $p$-value less than or equal to 0.05 ; I, insignificant trend with a $p$-value greater than 0.05$]$

\begin{tabular}{lllll}
\hline \multirow{1}{*}{ Period } & \multicolumn{3}{c}{ U.S. Geological Survey streamgages and station numbers } \\
\cline { 2 - 5 } & $\begin{array}{c}\text { Elkhorn River at Waterloo, } \\
\text { Nebr., station } \mathbf{0 6 7 9 8 5 0 0}\end{array}$ & $\begin{array}{c}\text { Logan Creek near Uehling, } \\
\text { Nebr., station } \mathbf{0 6 7 9 9 5 0 0}\end{array}$ & $\begin{array}{c}\text { Maple Creek near Nickerson, } \\
\text { Nebr., station 06800000 }\end{array}$ & $\begin{array}{c}\text { Elkhorn River at Waterloo, } \\
\text { Nebr., station 06800500 }\end{array}$ \\
\hline Annual ${ }^{1}$ & $\mathrm{P}(0.01)$ & $\mathrm{P}(0.00)$ & $\mathrm{P}(0.02)$ & $\mathrm{P}(0.00)$ \\
January & $\mathrm{P}(0.01)$ & $\mathrm{P}(0.00)$ & $\mathrm{P}(0.01)$ & $\mathrm{P}(0.00)$ \\
February & $\mathrm{I}(0.09)$ & $\mathrm{P}(0.01)$ & $\mathrm{I}(0.26)$ & $\mathrm{I}(0.07)$ \\
March & $\mathrm{I}(0.36)$ & $\mathrm{I}(0.13)$ & $\mathrm{I}(0.56)$ & $\mathrm{I}(0.50)$ \\
April & $\mathrm{I}(0.20)$ & $\mathrm{P}(0.00)$ & $\mathrm{P}(0.01)$ & $\mathrm{P}(0.02)$ \\
May & $\mathrm{P}(0.05)$ & $\mathrm{P}(0.00)$ & $\mathrm{P}(0.01)$ & $\mathrm{P}(0.00)$ \\
June & $\mathrm{P}(0.03)$ & $\mathrm{P}(0.00)$ & $\mathrm{I}(0.12)$ & $\mathrm{P}(0.00)$ \\
July & $\mathrm{P}(0.00)$ & $\mathrm{P}(0.00)$ & $\mathrm{P}(0.00)$ & $\mathrm{P}(0.00)$ \\
August & $\mathrm{I}(0.13)$ & $\mathrm{P}(0.00)$ & $\mathrm{P}(0.00)$ & $\mathrm{P}(0.01)$ \\
September & $\mathrm{I}(0.10)$ & $\mathrm{P}(0.00)$ & $\mathrm{P}(0.00)$ & $\mathrm{P}(0.01)$ \\
October & $\mathrm{I}(0.15)$ & $\mathrm{P}(0.00)$ & $\mathrm{P}(0.04)$ & $\mathrm{P}(0.01)$ \\
November & $\mathrm{P}(0.05)$ & $\mathrm{P}(0.00)$ & $\mathrm{P}(0.00)$ & $\mathrm{P}(0.00)$ \\
December & $\mathrm{P}(0.01)$ & $\mathrm{P}(0.00)$ & $\mathrm{P}(0.00)$ & $\mathrm{P}(0.00)$ \\
\hline
\end{tabular}

${ }^{1}$ Computation based on water year. A water year begins October 1 of the previous calendar year and ends September 30 of the year of interest. Thus, the water year ending September 30, 2011, is called the "2011 water year."

\section{Summary}

To better understand the streamflow trends at the streamgages on the Elkhorn River Basin, the U.S. Geological Survey (USGS), in cooperation with the Lower Elkhorn Natural Resources District, further investigated streamflow trends at the eight streamgages on the Elkhorn River, Salt Creek, and the Lower Platte River that indicated a positive trend in streamflow characteristics and analyzed precipitation trends in the four basins upstream from the Elkhorn River Basin streamgages. Trend analyses of four streamgages in the Elkhorn River Basin, one streamgage in the Salt Creek Basin, and three streamgages in the Platte River Basin that had previously indicated trends in various selected streamflow metrics (annual mean streamflow, annual low flows, fall low flows, and growing season monthly mean streamflows) were completed for the period from 1961 to 2011. One streamgage in the Elkhorn River Basin (Elkhorn River at Neligh, Nebraska [Nebraska Department of Natural Resources station 06798500]) had significant trends in annual mean streamflow but insignificant trends for other streamflow metrics, whereas the remaining three streamgage in the Elkhorn River Basin, all lower in the basin (Logan Creek near Uehling, Nebr. [USGS station 06799500]; Maple Creek at Nickerson, Nebr. [USGS station 06800000]; and Elkhorn River at Waterloo, Nebr. [USGS station 06800500]), had significant positive trends for annual mean streamflow, for all durations of the annual low-flow periods (1-day, 2-day, 3-day, 7-day, 14-day, 30-day, 60-day, 90-day, and 183-day periods), for all durations of the low-flow periods in October-November (1-day, 2-day, 3-day, 7-day, 14-day, 30-day, and 60-day periods), and for monthly mean streamflow for July, August, and September. Streamflow records for the Platte River near Duncan, Nebr. (USGS station 06774000), streamgage only indicated a significant trend in the August mean streamflow, no other metrics had significant trends at the streamgage.

Upstream from the confluence of the Elkhorn River and the Platte River, the Platte River at North Bend, Nebr. (USGS station 06796000), streamgage indicated insignificant trends for most streamflow metrics. Streamflows at the Salt Creek at Greenwood, Nebr. (USGS station 06803555), streamgage indicated positive trends in annual and October-November low flows and August mean streamflows but insignificant trends in annual mean streamflow and June, July, and September monthly mean streamflows. Streamflows at the Platte River at Louisville, Nebr. (USGS station 06805500), streamgage indicated significant positive trends in most annual and all October-November low flows and August mean streamflows but insignificant trends in annual mean streamflow and June, July, and September monthly mean streamflows.

The results indicate that positive trends in low flows in the Salt Creek and Elkhorn River streamgages may be contributing to positive trends in low flows for the Platte River at Louisville, Nebr., streamgage. Likewise, streamflow in the Salt Creek and Elkhorn River Basins may be contributing to the 
positive trend in August mean streamflow for the Platte River at Louisville, Nebr., streamgage, three lower Elkhorn River streamgages, and the Salt Creek streamgage.

The trend analyses are sensitive to the period that is analyzed for trends. Sites with the most significant trends for lowflow metrics for the period 1961-2011 have fewer significant trends for low-flow metrics for the period after 1980-2011. This result indicates that in the 20 -year period before about 1980 , the streams in this study carried less streamflow during low-flow periods than in the 30 years after. Annual mean streamflow trends remain significant at the Logan Creek near Uehling, Nebr.; Maple Creek at Nickerson, Nebr.; and Elkhorn River at Waterloo, Nebr., streamgages when the record is shortened until about 1974-2011; thereafter, the annual mean streamflow generally becomes insignificant. Similarly, low-flow trends remain significant at the Logan Creek near Uehling, Nebr.; Maple Creek at Nickerson, Nebr.; and Elkhorn River at Waterloo, Nebr., streamgages when the record is shortened to about 1976-2011; thereafter, fewer trends are significant.

Precipitation was examined as a primary cause for streamflow trends. Composite precipitation data series upstream from each of the four streamgages in the Elkhorn Basin (Elkhorn River at Neligh, Nebr.; Logan Creek near Uehling, Nebr.; Maple Creek near Nickerson Nebr.; and Elkhorn River at Waterloo, Nebr.) were synthesized by computing an area-weighted mean of volumes reported from precipitation gages in and around the study area and were summarized for each month or year. Of the four sites, only Elkhorn River at Neligh, Nebr., indicated a significant increase in annual precipitation. In general, the goodness of fit for the linear relations was poor with coefficient of determination values of less than or equal to 0.10 for four of the eight relations. When separated into monthly precipitation, few trends were indicated, with only 4 of the 48 site-month combinations indicating significant trends. Only one significant increase in annual precipitation upstream from the streamgages and the frequent detection of significant increases in streamflow after removing the effect of precipitation indicate that other factors besides precipitation may have played a role in the positive trends in low-flow periods in the lower Elkhorn River and its tributaries.

\section{References Cited}

Bentall, R., and others, 1971, Water supplies and the landThe Elkhorn River Basin of Nebraska: University of Nebraska-Lincoln, Institute of Agriculture and Natural Resources, Conservation and Survey Division, $51 \mathrm{p}$.
Conservation and Survey Division, University of NebraskaLincoln, 2019, Till—Geology related GIS data: University of Nebraska-Lincoln, Institute of Agriculture and Natural Resources, digital data, accessed May 14, 2019, at http://snr.unl.edu/csd-esic/download/geographygis/utm/ till_utm.zip.

Diamond, H.J., Karl, T.R., Palecki, M.A., Baker, C.B., Bell, J.E., Leeper, R.D., Easterling, D.R., Lawrimore, J.H., Meyers, T.P., Helfert, M.R., Goodge, G., and Thorne, P.W., 2013, U.S. Climate Reference Network after one decade of operations - Status and assessment: Bulletin of the American Meteorological Society, v. 94, no. 4, p. 485-498. [Also available at https://doi.org/10.1175/BAMS-D-1200170.1.]

Dietsch, B.J., Godberson, J.A., and Steele, G.V., 2009, Trends in streamflow characteristics of selected sites in the Elkhorn River, Salt Creek, and Lower Platte River basins, eastern Nebraska, 1928-2004, and evaluation of streamflows in relation to instream-flow criteria, 1953-2004: U.S. Geological Survey Scientific Investigations Report 2009-5011, 93 p. with appendixes. [Also available at https://doi.org/10.3133/sir20095011.]

Helsel, D.R., and Hirsch, R.M., 1992, Statistical methods in water resources: U.S. Geological Survey Techniques of Water-Resources Investigations, book 4, chap. A3, 522 p. [Also available at https://doi.org/10.3133/twri04A3.]

Lins, H.F., and Slack, J.R., 1999, Streamflow trends in the United States: Geophysical Research Letters, v. 26, no. 2, p. 227-230. [Also available at https://doi.org/10.1029/ 1998GL900291.]

Linsley, R.K., Kohler, M.A., and Paulhus, J.L.H., 1982, Hydrology for engineers 3rd ed.: New York, McGrawHill, 508 p.

McCabe, G.J., Jr., and Wolock, D.M., 2002, A step increase in streamflow in the conterminous United States: Geophysical Research Letters, v. 29, no. 24, p. 38-1-38-4. [Also available at https://doi.org/10.1029/2002GL015999.]

Nebraska Department of Natural Resources, 2013, In the matter of appropriations A-17329, A-17330, A-17331 and A-17332: Nebraska Department of Natural Resources, accessed November 22, 2017, at http://outdoornebraska.gov/ wp-content/uploads/2015/11/Platte-River-Instream-Flow15-year-review2013.pdf.

Nebraska Department of Natural Resources, 2017, Streamgaging stations list-Active NeDNR and USGS stream gages/links to gage data: Nebraska Department of Natural Resources, accessed August 1, 2017, at https://nednr.nebraska.gov/RealTime/Stations/Index. 
Norton, P.A., Anderson, M.T., and Stamm, J.F., 2014, Trends in annual, seasonal, and monthly streamflow characteristics at 227 streamgages in the Missouri River watershed, water years 1960-2011: U.S. Geological Survey Scientific Investigations Report 2014-5053, 128 p. [Also available at https://doi.org/10.3133/sir20145053.]

Rus, D.L., Dietsch, B.J., and Simon, A., 2003, Streambed adjustment and channel widening in eastern Nebraska: U.S. Geological Survey Water-Resources Investigations Report 03-4003, 63 p. [Also available at https://doi.org/10.3133/ wri034003.]

Steele, G.V., and Verstraeten, I.M., 1999, Effects of pumping collector wells on river-aquifer interaction at Platte River Island near Ashland, Nebraska, 1998: U.S. Geological Survey Water-Resources Investigations Report 99-4161, 6 p. [Also available at https://doi.org/10.3133/wri994161.]

U.S. Geological Survey, 2017, USGS water data for the Nation: U.S. Geological Survey National Water Information System database, accessed August 1, 2017, at https://doi.org/10.5066/F7P55KJN.
U.S. Soil Conservation Service, 1970, Major land resource areas (MLRA): Adapted from the U.S. Soil Conservation Service by the U.S. Geological Survey, scale 1:2,000,000, http://water.usgs.gov/GIS/metadata/usgswrd/XML/ mlra.xml.

Venables, W.N., Smith, D.M., and the R Development Core Team, 2017, An introduction to $\mathrm{R}$ - Notes on $\mathrm{R}-\mathrm{A}$ programming environment for data analysis and graphics, version 3.5.0 under development (2017-10-28): The Comprehensive R Archive Network, 102 p., accessed March 14, 2013, at http://cran.rproject.org/doc/manuals/Rintro.pdf.

Wen, F., and Chen, X., 2006, Evaluation of the impact of groundwater irrigation on streamflow in Nebraska: Journal of Hydrology (Amsterdam), v. 327, no. 3-4, p. 603-617. [Also available at https://doi.org/10.1016/ j.jhydrol.2005.12.016.] 
For more information about this publication, contact: Director, USGS Nebraska Water Science Center 5231 South 19th Street

Lincoln, NE 68512

402-328-4100

For additional information, visit: https://www.usgs.gov/centers/ne-water

Publishing support provided by the

Rolla Publishing Service Center 
